OECD Working Papers on Public Governance No. 30

\section{OECD 2017 OURdata} Index: Methodology and results
Guillaume Lafortune, Barbara Ubaldi 


\section{PUBLIC GOVERNANCE WORKING PAPER}

OECD OURdata INDEX 2017: METHODOLOGY AND RESULTS

Guillaume Lafortune, Economist, OECD

Barbara Ubaldi, Senior Project Manager/Senior Policy Analyst, OECD 


\begin{abstract}
This paper presents the process, methodology and results of the OECD 2017 Open-Useful-Reusable Government data Index (OURdata Index). This paper has three key objectives. First, it describes the design, content and methodology of the OECD 2017 OURdata Index and outlines the data collection and verification process. Second, it presents key findings of the composite indicators including overall country scores and scores by pillars and sub-pillars. Third, the paper presents the outcomes of different statistical tests to assess the robustness of the results, including tests to evaluate the sensitivity of the indicators to various weighting schemes. It concludes by highlighting the limitations of the Index and calls for further research on the impact of open government data policies and practices, in particular the relationship between open government policies and socio-economic outcomes as well as the performance and efficiency of public sector organisations.
\end{abstract}




\section{Table of Contents}

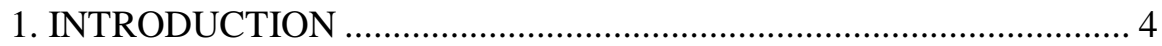

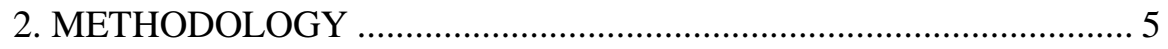

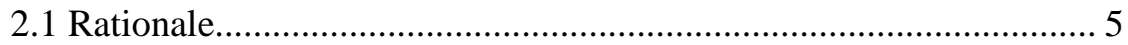

2.2 Survey design and data validation.................................................... 6

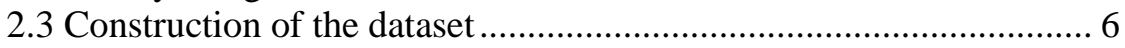

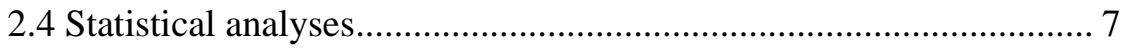

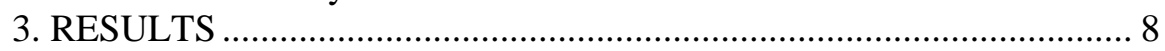

3.1 The OURdata Index framework ............................................. 8

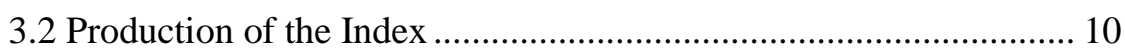

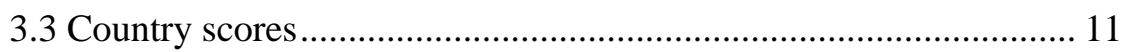

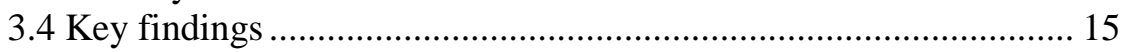

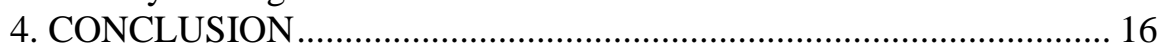

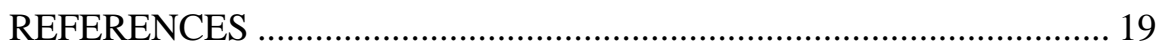

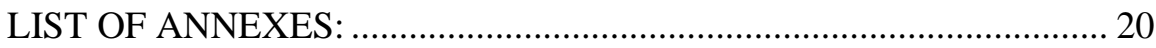

Annex A: Main international benchmarks on open government data ... 21

Annex B: Timeline for developing the 2017 OURdata Index ................ 23

Annex C: Detailed list of variables included in the OURdata Index 201724

Annex D: List of sub-principles from the International Open Data Charter not covered in the 2017 OECD

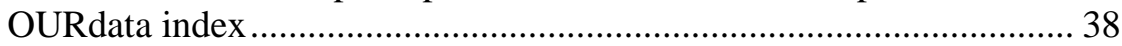

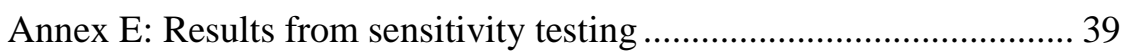

Annex F: Exploring validity (construct and convergent) and reliability 42 


\section{INTRODUCTION}

The OECD 2017 Open-Useful-Re-Usable Government Data Index (OURdata Index) presents information on open government data (OGD) policies and practices in 31 OECD countries based on the International Open Data Charter. The indicators cover, in detail, all 6 key principles. The information presented in the indicators shows the situation in OECD member countries as of 31 December 2016. As it is envisaged to update the information on a regular basis, these indicators are designed to allow countries to easily compare their progress in different areas of OGD policies and practices over time.

The OECD 2017 OURdata Index was published for the first time in the flagship report Government at a Glance 2017 (OECD, 2017). A pilot version was released in the previous edition of Government at a Glance 2015 (OECD, 2015). A forthcoming OECD report will analyse in greater detail the results and insights from the OURdata Index. Information on the OECD work on OGD is available at http://www.oecd.org/gov/digital-government/open-government-data.htm. Composite indicator scores and the full disaggregated dataset underlying the indicators are available at http://www.oecd.org/gov/government-at-a-glance-2017-database.htm.

This paper has three key objectives. First, it describes the design, content and methodology of the OECD 2017 OURdata Index and outlines the data collection and verification process. Second, it presents key findings of the composite indicators including overall country scores and scores by pillars and sub-pillars. Third, the paper presents the outcomes of different statistical tests to assess the robustness of the results including tests to evaluate the sensitivity of the indicators to various weighting schemes.

Overall, this assessment reveals that the 2017 OECD OURdata Index is statistically sound in terms of coherence and balance. The three pillars which form the overall index (data availability, data accessibility, and government support for the re-use of data) seem to measure distinct aspects of a common underlying phenomenon. This is supported by the moderately strong level of correlation found across the three pillars. The overall score and the pillar scores are also moderately sensitive to changes in the weightings assigned based on Monte Carlo analysis. Finally, various tests used to evaluate convergent validity (whether the measure correlates well with other proxy measures of the same concept) and construct validity (whether the measure behaves as suggested by theory and common sense) appear satisfactory. Further research is, however, needed to assess empirically the relationship between open data policies and practices and broader societal outcomes including economic and social outcomes and the performance and efficiency of the public sector. 


\section{METHODOLOGY}

\subsection{Rationale}

The issue of data-driven governments - that is, those that are capable of using data as a strategic asset to increase public sector performance, openness and transparency -- has gained momentum over the past decade. This can be attributed to two phenomena. First, there is a growing consensus that open government is necessary to re-connect citizens with their government in the aftermath of the global financial crisis. An important and growing segment of the population in OECD countries do not trust public authorities and believe that public policies have been captured by vested interests. The creation of the Open Government Partnership in 2011 illustrates this growing focus on ensuring high levels of openness and transparency in government to address these concerns. Second, the proliferation of digital technologies creates new opportunities for the processing and re-use of the wealth of data collected and produced by public agencies in their day-to-day activities. New forms of partnerships and collaboration between the public sector and the broad set of actors of the open government data ecosystem enable the creation of innovative services and can support more data-driven policymaking.

This growing focus on new forms of public value co-creation has led to increased efforts by countries, regions, cities and organisations to implement the right mix of policies and practices, and to monitor their performance. Focusing on open government data, the European Commission, the Open Knowledge Foundation and the World Wide Web Foundation have all launched initiatives to monitor government performance in OGD at the central/federal level (see annex A). The Open Government Partnership Independent Reporting Mechanism also includes an evaluation of open data policies, but it is tailored to country objectives and action plans and the results are therefore not comparable internationally.

The OECD 2017 OURdata Index is the only indicator available that measures in detail government efforts to support OGD. It identifies implementation gaps, the existence of oversight mechanisms and the extent to which requirements apply to the whole government or only to certain ministries and agencies. The objective of the Index is to measure the level of "data availability, data accessibility and government support for the re-use of data based on the IODC principles". It relies on a single source of information: a survey instrument collected from high level government officials.

The survey instrument and indicator is based on the expertise of the OECD in this area and on a roadmap developed in 2013 (Ubaldi, 2013). The OECD Open Data expert group, created in 2014 and composed of high-level government officials from member and partner countries, provided feedback on early versions of the survey instrument and indicator. The survey goes beyond assessing the number of open datasets available and evaluates the extent to which formal requirements have been adopted to support OGD and whether these requirements are implemented in practice by central/federal ministries and agencies.

Unlike the Open Data Barometer, the Index does not measure the impact of open government data on socioeconomic outcomes. Rather, it evaluates whether governments provide the enabling conditions to stimulate data re-use, including organising awareness events for businesses and civil society and training for civil servants. As such, the indicator can be used for triangulation purposes with other indicator sets that rely primarily on opinions from civil society experts (Open Data Barometer and Global Open Data Index). 


\subsection{Survey design and data validation}

The data were collected via the OECD Survey on Open Government Data conducted between October and December $2016^{1}$. Respondents were high-level government officials (in many cases the National Chief Information Officer). The survey instrument and indicator were designed in consultation with the OECD Expert Group on Open Government Data. The survey is composed of 80 questions representing about 170 data points (a number of questions include sub-questions). This survey is designed to monitor the implementation of the International Open Data Charter (IODC) adopted in October 2015. The IODC is the most comprehensive international instrument currently available that provides a set of principles on open government data. This adds to the normative framework provided by the OECD Recommendation for enhanced access and more effective use of Public Sector Information (PSI) (OECD, 2008b).

The first pilot edition of the OURData Index released in 2015 was based on the G8 Open Data Charter adopted in 2013.This second edition (2017) of the OURdata Index has been strengthened to cover the principles of the International Open data Charter (IODC). For this reason, results from the pilot edition of the OURdata Index 2015 and those from the Index 2017 cannot be compared at the moment. Comparability over time should be ensured as of the 2017 edition.

Various steps were included in the process to ensure the highest standards in data quality and accuracy, both before the survey was launched (the survey was piloted in different jurisdictions, a glossary of key terms was included, consultations with pilot countries were organised to clarify some issues) and after the data were collected (checking for internal and external consistency in the survey responses, comparing the answers to previous answers, verifying that supporting evidence was systematically provided before validating responses).

The detailed timeline for data collection is provided in annex B.

\subsection{Construction of the dataset}

All responses were recoded using numerical values with a maximum value equal to "1" corresponding to the best practices. Variables were re-coded in the following way:

- Questions on formal requirements: A value of 1 was awarded for the existence of requirements that apply to the entire government, a value of 0.5 was awarded for the existence of requirements adopted by some ministries/agencies and a value of 0 for the absence of formal requirements.

- Frequency type questions: A value of 1 was awarded for often, a value of 0.75 for most/sometimes, a value of 0.25 for some/rarely and a value of 0 for never. Most frequency type questions associated "sometimes" to " $50-99 \%$ " of the time and some/rarely to " $1-49 \%$ " of the time. Therefore the numerical values assigned correspondence to the average shares for both categories of answers.

\footnotetext{
${ }^{1}$ Data were collected for all OECD member countries with the exception of Hungary, Iceland and Luxembourg who did not return the questionnaire.
} 
- Binary type questions (Yes/No): For the large majority of the questions a value of 1 was awarded for "Yes" and a value of 0 for "No".

There were no missing values in the questionnaires that were returned and therefore no estimations and imputations of values had to be produced.

\subsection{Statistical analyses}

The construction of the index follows the guidelines from the OECD/EU Handbook on Constructing Composite Indicators (2008). Four main types of analyses were conducted with the data to ensure the highest standards in terms of validity and reliability of the indicators (OECD-EU, 2008):

- Correlation analysis

Correlation analysis was conducted with three objectives. First, to identify groups among the large range of data collected. Second, to identify variables that are extremely highly correlated and that might denote signs of redundancy/collinearity. Variables with high collinearity were either dropped or merged into a single variable to avoid double counting and over-weighting certain responses. Third, to test the accuracy of the indicators produced and, notably, convergent validity (whether the measure correlates well with other proxy measures of the same concept) and construct validity (whether the measure behaves as suggested by theory and common sense) (Gonzalez and al, 2017).

\section{- Confirmatory Principal-Component Factor analysis}

Factor analysis is a statistical check that examines how a set of variables are associated and whether they are correlated with each other. Factor analysis is based on the idea that if there is a significant correlation among the variables that constitute a composite, then no essential insight is lost by reducing this large set of variables into a smaller one (e.g. a composite). From a technical point of view, correlated original variables can be transformed through linear combinations into a new, smaller set of uncorrelated underlying variables that form a composite index.

Confirmatory factor analysis was conducted to inform the final version of the indicator. However, considering the limited number of observations $(n=31)$ and the type of data (primarily categorical binary data) principal components analysis was mainly used as a 'search-light' in helping to identify unexpected trends (Arndt and al, 2015).

- Cronbach alpha testing (scale reliability coefficient)

Cronbach's Alpha is a coefficient of reliability based on the correlations between indicators. This statistic is generally used to investigate the degree of correlation among a set of variables and to check the internal reliability of items in a model or survey. A Cronbach's alpha coefficient equal to zero means that the variables are independent (e.g. the selection is not correlated and therefore is statistically not relevant), while a coefficient equal to one means that the variables are perfectly correlated. In general, a coefficient of above 
0.7 is considered to be an acceptable indication that the variables are measuring the same underlying construct.

- Sensitivity testing (Monte Carlo Simulation) (see Annex D)

Sensitivity testing was conducted to verify the sensitivity of the indicators created based on different weighting schemes. Monte Carlo simulations were run to test the sensitivity of the composite indicators to different weighting schemes. This technique uses 1000 sets of randomly generated simulated weights to calculate possible composite indicator scores for each country under different weighting schemes. This is equivalent to assuming uncertainty about the most appropriate value of each of the individual weights assigned to construct the composite indicators (Arndt and al, 2015).

\section{RESULTS}

\subsection{The OURdata Index framework}

The framework of the 2017 OURdata Index is an extended version of the original framework presented in the 2015 pilot version of the Index published in Government at a Glance 2015 and approved by the Public Governance Committee (OECD, 2015). Based on the OECD expertise on the topic, multivariate analyses and regular discussions with the OECD expert group on Open Government Data, the original framework comprises 3 key pillars: Data availability, Data accessibility and Government support for data re-use. Each pillar aims to capture whether formal requirements have been adopted, whether these are implemented in practice and whether continuous improvements are informed through regular interactions with users and stakeholder engagement. To assess implementation, Pillars 1 and 2 rely on data provided by the central/federal open data portal (also called "one-stop shop portal") and the analysis of the portal was used to check and probe the data, whereas Pillar 3 relies on evidence provided by government officials . 
Open-Useful Reusable Government data (OURdata Index), 2017: Pillars and Sub-pillars
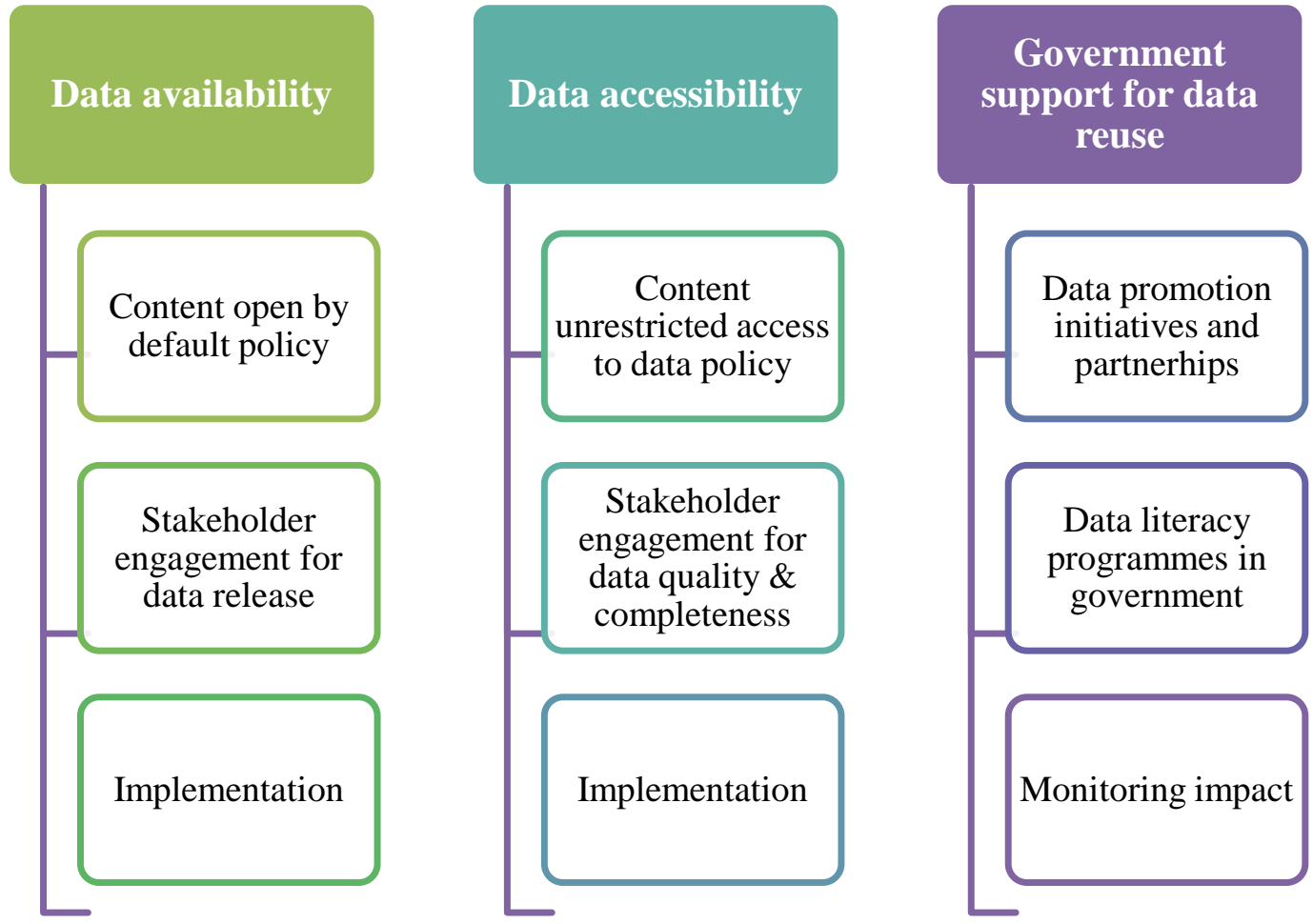

Source: OECD

Pillar 1 "Data availability" measures the extent to which governments have adopted and implemented formal requirements to promote open government data at the central/federal level. It covers primarily Principle 1 "Open by default" and 2 "Timely and comprehensive" of the IODC (see annex C).

1.1 Content of open by default policy: Measures whether there are formal requirements whereby data should be open by default and whether all exceptions to this rule are clearly identified. This pillar assesses whether the open by default policy is evidence-based (informed by regular reports, and statistics), whether the requirements apply to all or some government agencies and whether there are performance incentives for agencies to support effective implementation in practice.

1.2 Stakeholder engagement for data release: Measures the extent to which the release of open government data by central/federal agencies and ministries is informed by regular consultations with stakeholders and users of data.

1.3 Implementation (scope and breadth of data availability on the central/federal open data portal): Measures the number and scope of datasets made available on the central/federal open data portal. The assessment is based on the list of high value datasets identified in the G8 Open data Charter (2013). 
Pillar 2 "Data accessibility" measures the extent to which government data are provided in open and reusable formats with their associated metadata. It covers primarily principles 3 "Accessible and usable" and 4 "Comparable and interoperable" of the IODC.

2.1 Content of the unrestricted access to data policy: Measures whether there are requirements whereby government data should be provided free of charge, with an open license and in a timely and disaggregated manner.

2.2 Stakeholder engagement for data quality and completeness: Measures the extent to which data accessibility is informed through regular interactions with users and whether users can play an active role in monitoring platforms the quality and increasing the completeness of available data on the central/federal open data portal.

2.3 Implementation (data accessibility on the Central/federal open data portal): Measures the extent to which government data are provided on the central/federal portal free of charge, with an open license, in machine-readable and multiple formats and whether licensing conditions and metadata are systematically provided with the datasets.

Pillar 3 "Government support for data reuse" measures the extent to which governments play a proactive role in promoting the re-use of government data inside and outside government. It covers primarily Principle 5 "Improved Governance and Citizen Engagement" and 6 "Inclusive Development and Innovation" of the IODC.

3.1 Data promotion initiatives and partnerships: Measures the extents to which central/federal governments promote data awareness initiatives, data reuse initiatives and co-creation events (such as hackathons) and partnerships targeting businesses and the civil society.

3.2 Data literacy programmes in government: Measures the extent to which central/federal governments promote data reuse inside governments primarily through the use of information sessions and training events.

3.3 Monitoring impact: Measures the extent to which governments evaluate the socio economic impact and impact on public sector performance of open government data to support continuous improvement.

See annex D for a list of sub-principles (6 in total) not covered in this year's edition of the Index.

\subsection{Production of the Index}

The construction of the OURdata Index 2017 is based on 140 number of data points. There is no rule on the number of variables that should be included in a composite construct, but, compared to other composite constructs produced in the OECD Public Governance Directorate, this falls between the number of variables usually included for human resources management (HRM) composites (6-10 variables) (OECD, 2017) and the number of variables used to compute the Ireg indicators $(1,500)(\mathrm{OECD}, 2015)$. 
Each pillar of the Index (data availability, data accessibility, and government support for data reuse) has three sub-pillars (e.g. content of the open by default policy). The score for each pillar corresponds to an unweighted simple average of each sub-pillar ${ }^{2}$. At the sub-pillar level, implicit weighting was avoided since three sub-pillars were systematically retained under each main pillar.

Each sub-pillar has parameters (factors) identified via expert judgement and factor analysis. The score of each sub-pillar is computed as the unweighted simple average of each parameter. There are 9 parameters in Pillar 1, 8 parameters in Pillar 2 and 7 parameters in Pillar 3.

\subsection{Country scores}

The figures below provide the detailed country scores on the overall index, on each pillar and each sub-pillar. It also provides the list of parameters included under each sub-pillars as well as chronbach alpha scores and number of data points from the survey included.

OURdata Index: Overall ranking, 2017

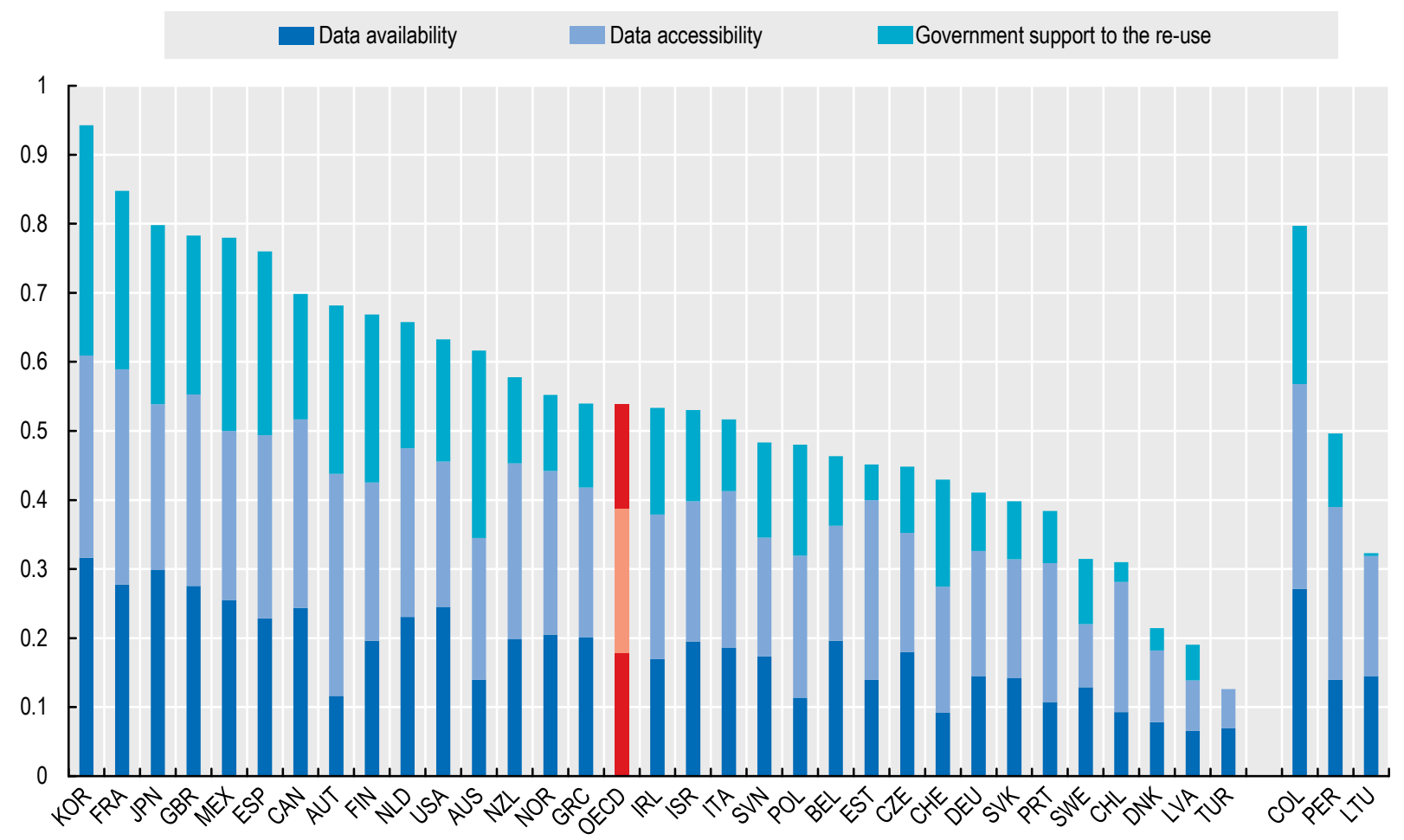

Note: Data not available for Hungary, Iceland and Luxembourg.

Number of items: 140. Chronbach alpha: 0.9637. Based mainly on the International Open data Charter.

Source: OECD 2016 Survey on Open Government Data 3.0

\footnotetext{
${ }^{2}$ Considering the type of data used (mainly categorical and binary data) the use of the geometric mean was not retained.
} 


\section{Pillar 1: Data availability}

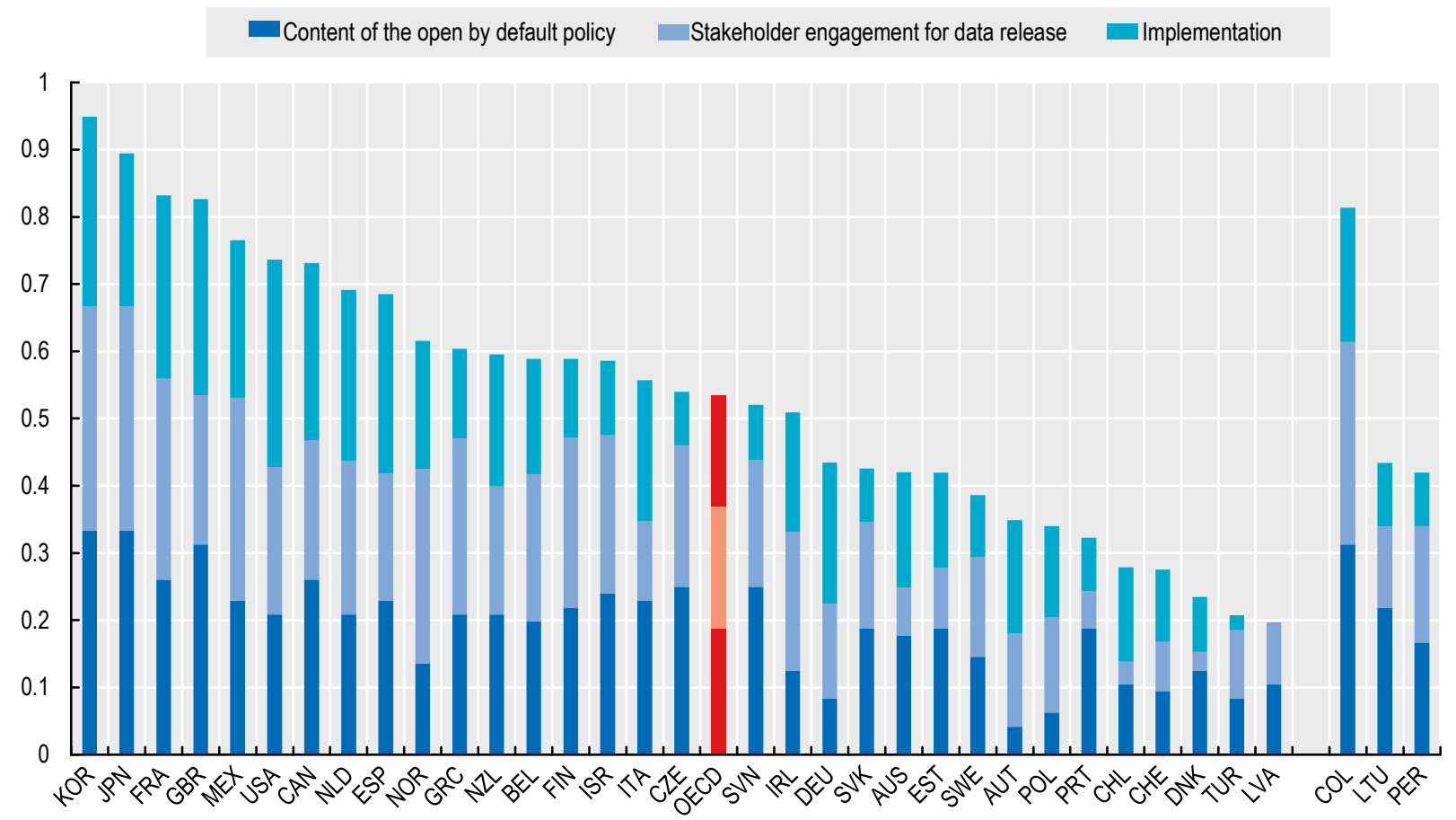

Note: Data not available for Hungary, Iceland and Luxembourg.

Number of items: 74. Chronbach alpha: 0.8767. Based mainly on Principles 1 and 2 of the International Open data Charter.

Source: OECD 2016 Survey on Open Government Data 3.0

\section{Pillar 1 - Detailed sub-pillars and parameters:}

\subsection{Content of open by default policy $(33.3 \%)$}

- Existence of an Open by default policy

- Clear identification of legitimate exceptions to the open by default rule

- Compliance with privacy legislation

- Performance incentives for public officials

\subsection{Stakeholder engagement for data release $(33.3 \%)$}

- Existence of formal requirements to consult stakeholders for data release

- Frequency of stakeholder consultations on open data plans

- Requirements to maintain lists of data holdings in each ministries/agencies to support effective consultations

\subsection{Implementation (33.3\%)}

- Total number of datasets available on the central/federal open data portal (tabular data only)

- Availability of high value datasets (as identified in the G8 Open data Charter) 


\section{Pillar 2: Data accessibility}

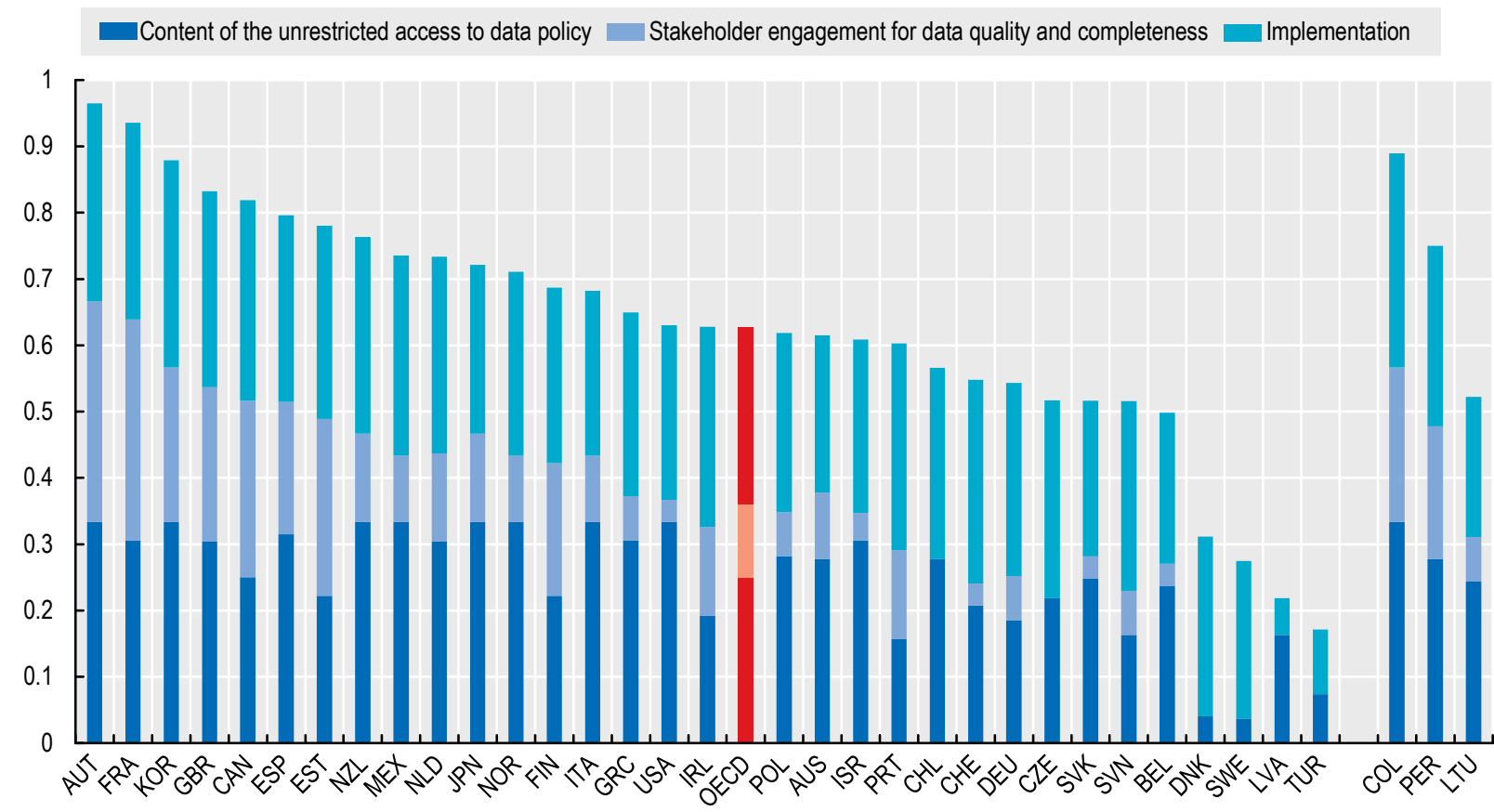

Note: Data not available for Hungary, Iceland and Luxembourg.

Number of items: 29. Chronbach alpha: 0.9058. Based mainly on Principles 3 and 4 of the International Open data Charter. Source: OECD 2016 Survey on Open Government Data 3.0

\section{Pillar 2 - Detailed sub-pillars and parameters:}

\subsection{Content of the unrestricted access to data policy $(33.3 \%)$}

- Existence of requirements on open license, formats and metadata

- Existence of requirements to provide access to data free of charge

- Existence of requirements to provide timely access to disaggregated data

\subsection{Stakeholder engagement for data quality and completeness $(33.3 \%)$}

- Feedback mechanisms on the central/federal data portal

- User driven central/federal data portal

\subsection{Implementation (33.3\%)}

- Adoption of a single entry point to access Open Government Data

- Data accessible free of charge and in open formats on the central/federal data portal

- Systematic provision of supporting information with datasets (licensing conditions, metadata) 


\section{Pillar 3: Government support for data re-use}

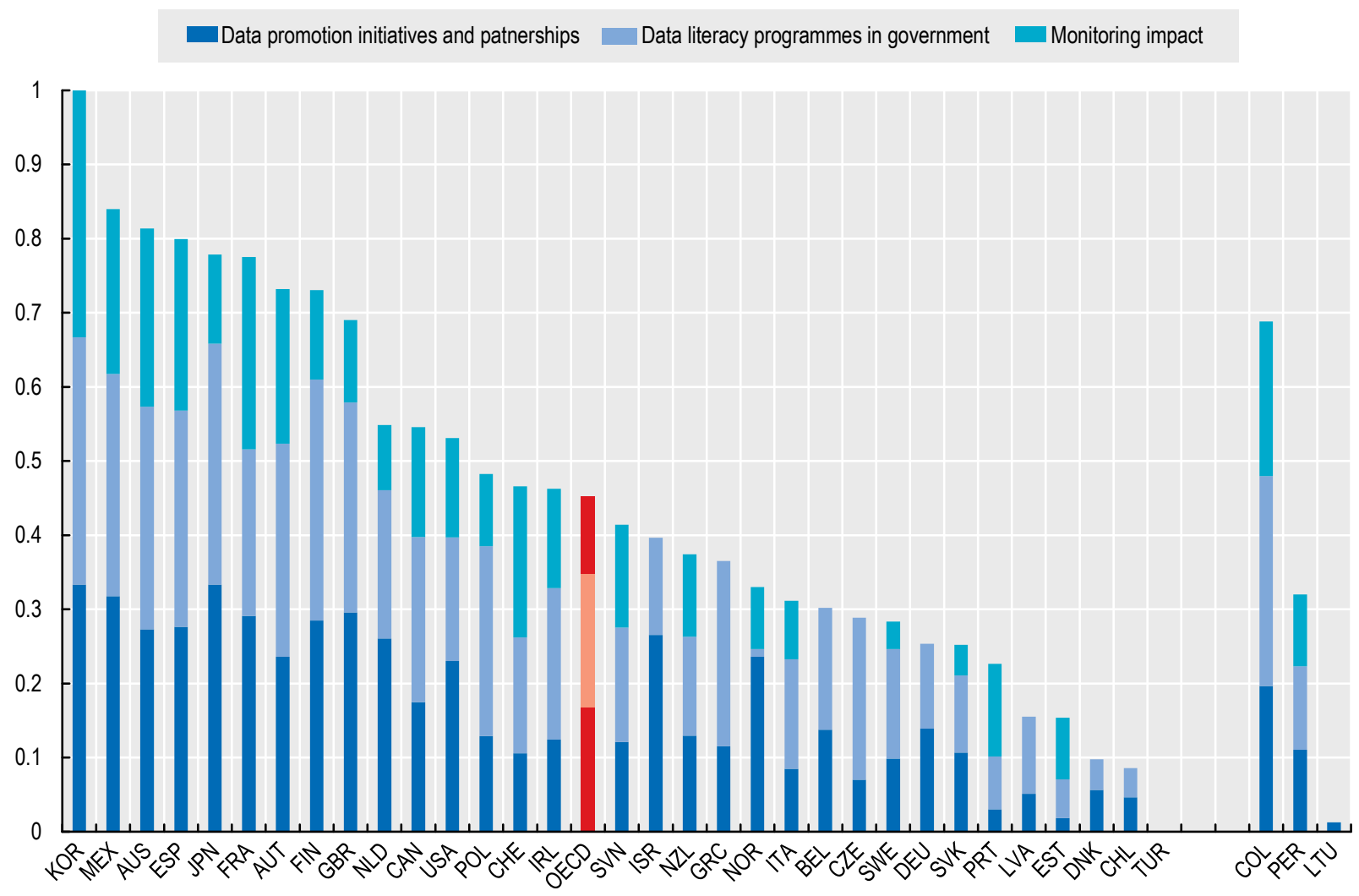

Note: Data not available for Hungary, Iceland and Luxembourg.

Number of items: 37. Chronbach alpha: 0.9475. Based mainly on Principles 5 and 6 of the International Open data Charter. Source: OECD 2016 Survey on Open Government Data 3.0

\section{Pillar 3 - Detailed sub-pillars and parameters:}

\subsection{Data promotion initiatives and partnerships (33.3\%)}

- Existence of data awareness programmes for businesses and civil society

- Frequency of specific events to support data re-use among businesses and the civil society

- Existence of formal partnerships with businesses and the civil society to support data re-use

\subsection{Data literacy programmes in government $(33.3 \%)$}

- Frequency of training events for public officials to support data-reuse

- Frequency of information sessions and focus groups for public officials to support data-re-use

\subsection{Monitoring impact $(33.3 \%)$}

- Conducted or financed research on socio economic impact of open data

- Monitor and promote online initiatives re-using open government data 


\subsection{Key findings}

The OECD 2017 OURdata index highlighted a number of key findings:

- Proactive support for the re-use of OGD could be strengthened: Governments have put important efforts into setting up the formal requirements for disclosing a large quantity of datasets in open, unrestricted and re-usable formats. However, few governments take a proactive approach to encouraging the re-use of data both outside the public sector through data awareness initiatives, hackathons and co-creation events) and inside the public sector (via information sessions and regular training for civil servants). This is reflected by the lower average score on Pillar 3 (government support for data re-use) compared to Pillar 1 (data availability) and Pillar 2 (data accessibility) as presented below.

\begin{tabular}{|l|c|c|c|}
\hline & $\begin{array}{c}\text { Pillar 1: Data } \\
\text { availability }\end{array}$ & $\begin{array}{c}\text { Pillar 2: Data } \\
\text { accessibility }\end{array}$ & $\begin{array}{c}\text { Pillar 3: Government support } \\
\text { for data re-use }\end{array}$ \\
\hline OECD mean & 0.54 & 0.63 & 0.46 \\
\hline Standard deviation & 0.20 & 0.19 & 0.25 \\
\hline
\end{tabular}

Source: OECD analysis

- Implementation gaps in late adopters of OGD policies and practices: Early reformers or "trend setters"', such as Canada, France, Korea, the United Kingdom and the United States, have implemented their policies to a larger extent as reflected by their high score for pillar 1 both on the adoption and content of the open by default policy and high number of open datasets made available in their main open data portal. By contrast, a number of recent reformers in the area of OGD have yet to implement some of the policies introduced as reflected by lower scores on the implementation component of pillar 1 .

- Consultation with stakeholders is commonly used to inform OGD policies, but few countries have put in place platforms where users can play an active role in monitoring the quality and adding to available data.

- Few countries closely monitor the economic and social impact of OGD as well as its impact on public sector performance and productivity. Monitoring impact is necessary to support continuous improvement and better understand the impact of OGD reforms.

More in-depth analyses of the results will be provided in the forthcoming OECD report on Open Government Data (2018-forthcoming).

\footnotetext{
${ }^{3}$ Reference to "The Open Data Economy Unlocking Economic Value by Opening Government and Public Data" report published in 2013.
} 


\section{CONCLUSION}

Open government data (OGD) can be a powerful lever for social and economic development; and to strengthen public governance (e.g. by enabling a citizen-driven approach to the design of public services, by enhancing public sector efficiency and by spurring public sector integrity and accountability). The OECD OURdata Index (Open-Useful-Reusable data Index) is one of the tools developed by the OECD (together with country reviews) to support countries' work in the area of open government data. The Index highlights some of the strengths and weaknesses of central/federal governments' efforts in OECD member and partner countries on a selected set of indicators and helps identify potential areas for actions to ensure OGD availability, accessibility and reuse by public, private and civic actors. Additionally, the OURdata Index measures the level of implementation of the International Open Data Charter's principles at the central/federal level based on the policy framework developed by the OECD. In doing so, it provides practical guidance for countries in designing, implementing and evaluating OGD policies and initiatives to foster use and re-use for public value co-creation.

The 2017 edition of the Index shows that governments have made important efforts to support the provision of a large quantity of data in an open, free and accessible format but further work could be made to proactively support their re-use, as the extent to which countries conduct initiatives to promote data re-use outside and inside governments varies greatly. Moreover few countries monitor the economic and social impact of open data as well as the impact of open data on public sector performance. Data collected also suggest that there might be an implementation gap in a number of countries where policy developments have been introduced very recently. By contrast, the early adopters of OGD have been able to introduce and implement a large range of policies to promote data availability, accessibility and re-use.

Thirdly, few countries have developed a central/federal data portal conceived as an exchange, collaboration and crowdsourcing platform where users are empowered not only to submit data and provide feedback on the quality and type of data for continuous improvement, but also to promote collaborations for greater reuse and impact of data.

In interpreting the survey results, it is important to bear in mind the methodological limitations of composite indicators, particularly those that, as in the current survey, are based on categorical variables (Arndt and al, 2015). Composite indicators are useful for integrating large amounts of information into an easily understood format (Freudenberg, 2003). However, by their very nature, cross-country comparable indicators cannot be context specific and cannot fully capture the complex realities of open government data policies. While the current survey puts a strong focus on evidence and examples to support country responses, it does not constitute an in-depth assessment of the quality of country practices in open government data.

In-depth country reviews are therefore required to complement the indicators. Reviews provide readers with a more detailed analysis of the content, strengths and shortcomings of countries' open government data policies, as well as detailed and context-specific recommendations for improvement. OECD member countries have a wide range of governance structures, administrative cultures and institutional and constitutional settings that are important to take into consideration to fully assess open government data 
policies and practices. While these are taken into account in OECD member country peer reviews, it is not possible to reflect all these country-specific factors in a cross-country comparison of OGD practices. For instance, to assess implementation in Pillars 1 and 2, the OECD OURdata Index focuses primarily on direct and indirect data provision on the central/federal data portal. The creation of a central repository for open government data is one of the principles in the IODC. At the same time, a myriad of line ministries and agencies also provide open government data on their own portals and websites, which is not captured in the Index.

The results of composite indicators are always sensitive to methodological choices, unless country answers are homogeneous across all practices. It is therefore important to interpret the results of countries with similar scores with caution. Instead composite indicators should be seen as a means of initiating discussion and stimulating public interest (OECD/European Union/JRC, 2008). To ensure full transparency, the methodology for constructing the composite indicators and underlying data as well as the results of the sensitivity analysis to different methodological choices, including the weighting system, are publicly available at: http://www.oecd.org/gov/govataglance.htm.

Finally, this paper identifies several areas that would benefit from further research and analyses to push the open agenda forward:

- The role of oversight, monitoring and quality control bodies: The OURdata Index includes a number of metrics on whether monitoring and evaluation mechanisms are in place (primarily through official reports, statistics and research). In the future, additional metrics could be added to capture the role of oversight and quality control bodies, which contribute to ensuring high standards in terms of data quality, regular updates and compliance. Robust monitoring and evaluation helps ensures a more consistent approach to open data practices, better quality data, and improves the conditions for the sharing and re-use of open data.

- Monitoring of capacity and engagement of Open Government Data ecosystem: Public value creation through open data requires re-use by a number of actors. Efforts to strengthen the maturity of the broad ecosystem as well as of the public sector's efforts to understand and engage an inclusive set of actors from such ecosystem for the creation of different types of public value (i.e. social, economic and good governance).

- Synergy/collaborations across levels of government: The OURdata Index includes only the central/federal level of government. This covers all line ministries and agencies, but excludes subnational levels (regional and local governments). This makes the Index highly comparable, but it is an important limitation. In a number of countries a significant share of open data initiatives takes place at the regional and municipal level, especially when it comes to data re-use initiatives and data awareness events. While the focus of the OURdata Index will remain on the central/federal level of government, the indicator could explore how to better capture data interoperability and partnerships across levels of government while still taking into account institutional differences across countries (e.g. federal vs unitary states). 
- Linkages between OGD policies and outcomes: Ultimately the objective of the OURdata Index is to better capture the impact of OGD policies and practices on broader societal outcomes such as economic and social outcomes, as well as on the functioning of central/federal governments (e.g. productivity, service quality). The OECD will continue to work closely with members to improve methodologies to track the impact of open government data outside and inside government. For the moment, the knowledge base is being built primarily through specific case studies considering the important methodological barriers in measuring empirically the impact of open government data and the relationship between process and outcomes.

- Release of sectoral data (e.g. health, agriculture, etc.), prioritising sector packages of IODC: Increasing data availability and quality within specific sectors is an important way to engage and empower relevant actors within a specific community in data use and reuse for value creation. Working with the specific communities to identify high value datasets within sectors can help broaden political commitment to open up data, make the open data movement more user-driven, strengthen networks to address common challenges and connect with local communities. The OECD will focus on this particularly in collaboration with the IODC Secretariat.

- Private sector efforts to re-use Open Government Data (especially high value datasets): Private sector actors that host Open Government Data increasingly offer a "platform" for public and private users to collaborate in public value co-creation and in finding innovative solutions to complex policy issues. Given its capacity to host large datasets and interest in multiplying the value of this data, the private sector (in all its complexity and diversity) represents an important segment of the ecosystem that should be expected to increasingly re-use OGD for economic value creation.

- Further research on the role of the principles of the OECD PSI Recommendation and how they complement, overlap or conflict with the IODC. 


\section{REFERENCES}

Arndt, C. et al. (2015), "2015 Indicators of Regulatory Policy and Governance: Design, Methodology and Key Results”, OECD Regulatory Policy Working Papers, No. 1, OECD Publishing, Paris. http://dx.doi.org/10.1787/5jrnwqm3zp43-en

Cap Gemini Consulting. (2013). "The Open Data Economy: Unlocking Economic Value by Opening Government and Public Data". https://www.capgemini.com/wpcontent/uploads/2017/07/the open data economy unlocking economic value by opening government and public data.pdf

González, S., L. Fleischer and M. Mira d'Ercole (2017), "Governance statistics in OECD countries and beyond: What exists, and what would be required to assess their quality?", OECD Statistics Working Papers, No. 2017/03, OECD Publishing, Paris. http://dx.doi.org/10.1787/c0d45b5e-en

Koske, I., et al. (2015), "The 2013 update of the OECD's database on product market regulation: Policy insights for OECD and non-OECD countries", OECD Economics Department Working Papers, No. 1200, OECD Publishing, Paris.

OECD (2017), Government at a Glance 2017, OECD Publishing, Paris

http://dx.doi.org/10.1787/gov_glance-2017-en

OECD (2015), OECD Regulatory Policy Outlook 2015, OECD Publishing, Paris. http://dx.doi.org/10.1787/9789264238770-en

OECD (2008), "Quality Framework and Guidelines for OECD Statistical Activities”, OECD Publishing, Paris.

OECD (2008 b), Recommendation for enhanced access and more effective use of Public Sector Information (PSI)

OECD/European Union/JRC (2008), Handbook on Constructing Composite Indicators: Methodology and User Guide, OECD Publishing, Paris, http://dx.doi.org/10.1787/9789264043466-en.

Saisana, M. and A. Saltelli (2011), "Statistical tests on the WJP Rule of Law index", European Commission Joint Research Centre (available in the 2011 WJP Rule of Law Index Report at www.worldjusticeproject.org).

Ubaldi, B. (2013), "Open Government Data: Towards Empirical Analysis of Open Government Data Initiatives", OECD Working Papers on Public Governance, No. 22, OECD Publishing, Paris. http://dx.doi.org/10.1787/5k46bj4f03s7-en 


\section{LIST OF ANNEXES:}

Annex A: Main international benchmarks on open government data

Annex B: List of sub-principles from the IODC not covered in the 2017 OECD OURdata index

Annex C: Detailed underlying data

Annex D: List of sub-principles not covered

Annex E: Results from sensitivity testing

Annex F: Exploring validity (construct and convergent) and reliability 
Annex A: Main international benchmarks on open government data ${ }^{4}$

\begin{tabular}{|c|c|c|c|c|c|c|c|}
\hline Title of the assessment & Organization & Coverage & $\begin{array}{l}\text { Methodological } \\
\text { approach }\end{array}$ & Data source(s) & Frequency & Concept measured & Website \\
\hline Open Data Monitor & $\begin{array}{l}\text { European } \\
\text { Commission (and } \\
\text { consortium of } \\
\text { collaborators) }\end{array}$ & $\begin{array}{l}\text { Central/federal } \\
\text { government }\end{array}$ & $\begin{array}{l}\text { International } \\
\text { benchmark (EU } \\
\text { countries) }\end{array}$ & $\begin{array}{l}\text { Harvesting } \\
\text { (collecting } \\
\text { metadata from } \\
\text { external portals } \\
\text { and catalogues) }\end{array}$ & $\begin{array}{l}\text { One-off in } \\
2015\end{array}$ & $\begin{array}{l}\text { Reviews data catalogues in EU } \\
\text { member countries focusing on } \\
\text { metadata completeness, open } \\
\text { license, formats and scope and } \\
\text { data availability. }\end{array}$ & $\begin{array}{l}\text { http://opendatamonitor } \\
\text {.eu/frontend/web/index } \\
\text {.php?r=dashboard\%2F } \\
\text { indexhttps://opendatamo } \\
\text { nitor.eu/frontend/web/ind } \\
\text { ex.php?r=dashboard\%2F } \\
\text { index\# }\end{array}$ \\
\hline OURdata Index & OECD & $\begin{array}{l}\text { Central/federal } \\
\text { government }\end{array}$ & $\begin{array}{l}\text { International } \\
\text { benchmark }\end{array}$ & $\begin{array}{l}\text { Government } \\
\text { officials }\end{array}$ & $\begin{array}{l}\text { Every two } \\
\text { years }\end{array}$ & $\begin{array}{l}\text { Measures data availability, data } \\
\text { accessibility and government } \\
\text { support for the re-use of data } \\
\text { based on the IODC principles. }\end{array}$ & $\begin{array}{l}\text { http://www.oecd.org/gov } \\
\text { /digital- } \\
\text { government/open- } \\
\text { government-data.htm }\end{array}$ \\
\hline $\begin{array}{l}\text { Open Government } \\
\text { Partnership } \\
\text { Independent Reporting } \\
\text { Mechanism }\end{array}$ & OGP & $\begin{array}{l}\text { Central/federal } \\
\text { government }\end{array}$ & $\begin{array}{l}\text { Mainly } \\
\text { qualitative. } \\
\text { Tailored to } \\
\text { country contexts } \\
\text { and objectives. }\end{array}$ & $\begin{array}{l}\text { International } \\
\text { Experts Panel }\end{array}$ & $\begin{array}{l}\text { Annually } \\
\text { (rolling } \\
\text { basis) }\end{array}$ & $\begin{array}{l}\text { Progress reports assess } \\
\text { governments on the } \\
\text { development and } \\
\text { implementation of OGP action } \\
\text { plans, progress in fulfilling open } \\
\text { government principles, and } \\
\text { make recommendations for } \\
\text { improvements. }\end{array}$ & $\begin{array}{l}\text { https://www.opengovpart } \\
\text { nership.org/about/indepe } \\
\underline{\text { ndent-reporting- }} \\
\underline{\text { mechanism }}\end{array}$ \\
\hline $\begin{array}{l}\text { Global Open data } \\
\text { Index }\end{array}$ & $\begin{array}{l}\text { Open Knowledge } \\
\text { Foundation }\end{array}$ & $\begin{array}{l}\text { Central/federal } \\
\text { government }\end{array}$ & $\begin{array}{l}\text { International } \\
\text { benchmark }\end{array}$ & Crowdsourcing & Annually & $\begin{array}{l}\text { An independent assessment of } \\
\text { open government data } \\
\text { publication from a civic } \\
\text { perspective. }\end{array}$ & https://index.okfn.org/ \\
\hline Open Data Barometer & $\begin{array}{l}\text { World Wide Web } \\
\text { Foundation }\end{array}$ & $\begin{array}{l}\text { Central/federal } \\
\text { government }\end{array}$ & $\begin{array}{l}\text { International } \\
\text { benchmark. }\end{array}$ & $\begin{array}{l}\text { Mix of sources } \\
\text { (peer reviewed } \\
\text { expert survey, } \\
\text { government }\end{array}$ & Annually & $\begin{array}{l}\text { Measures governments' open } \\
\text { data readiness, implementation } \\
\text { and impact based on the IODC } \\
\text { principles. }\end{array}$ & $\begin{array}{l}\text { http://opendatabarometer } \\
. \text { org/ }\end{array}$ \\
\hline
\end{tabular}

\footnotetext{
${ }^{4}$ These are the main benchmarks focusing on open government data. There are other benchmarks with a broader focus such as the World Justice Project Open Government Index (https://worldjusticeproject.org/our-work/wjp-rule-law-index/wjp-open-government-index-2015) and the Transparency International Corruption Perception Index (https://www.transparency.org/research/cpi/overview).
} 


\begin{tabular}{|l|l|l|l|l|l|}
\hline & & & $\begin{array}{l}\text { self-assessment, } \\
\text { secondary data) }\end{array}$ & & \\
\hline
\end{tabular}

Source: OECD analysis 
Annex B: Timeline for developing the 2017 OURdata Index

\begin{tabular}{|c|c|}
\hline April 2016 & $\begin{array}{l}\text { - } 2^{\text {nd }} \text { OECD Open Data Expert Group meeting } \\
\text { - } \quad \text { Discuss the focus of the next data collection and process } \\
\text { towards the production of the } 2017 \text { OURdata Index }\end{array}$ \\
\hline May-August 2016 & $\begin{array}{l}\text { - Development of the survey instrument } \\
\text { - Production of the glossary of terms } \\
\text { - Integration of the survey in the online platform }\end{array}$ \\
\hline September-October 2016 & $\begin{array}{l}\text { - Survey piloted in } 10 \text { OECD countries } \\
\text { - Integration of the comments and final revisions to the survey }\end{array}$ \\
\hline November-December 2016 & $\begin{array}{l}\text { - Data collection period } \\
\text { - Regular interactions with survey respondents to clarify } \\
\text { certain concepts and survey questions }\end{array}$ \\
\hline January-February 2017 & $\begin{array}{l}\text { - Data validation process conducted by the OECD Secretariat } \\
\text { to ensure internal and external consistency of the data } \\
\text { collected } \\
\text { - Regular interactions with survey respondents to verify } \\
\text { responses and evidence provided }\end{array}$ \\
\hline March-April 2017 & 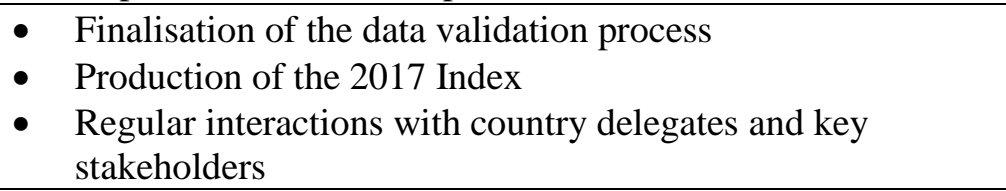 \\
\hline May 2017 & $\begin{array}{l}\text { - Presentation of the Index and key results at the } 3^{\text {rd }} \text { OECD } \\
\text { Open Data Expert Group meeting } \\
\text { - Integration of comments and final minor changes }\end{array}$ \\
\hline 13 July 2017 & $\begin{array}{l}\text { - Launch of Government at a Glance } 2017 \text { (including the } \\
\text { OECD } 2017 \text { OURdata Index) }\end{array}$ \\
\hline
\end{tabular}


Annex C: Detailed list of variables included in the OURdata Index 2017

Pillar 1 - Data availability

\begin{tabular}{|c|c|c|c|c|c|c|}
\hline $\mathbf{N}^{\circ}$ & Pillar & Sub-pillar & Parameter & Variable & Response options & $\begin{array}{c}\text { IODC } \\
\text { principle } \\
\end{array}$ \\
\hline 1 & Data availability & $\begin{array}{l}\text { Content of the open by } \\
\text { default policy }\end{array}$ & $\begin{array}{l}\text { Existence of an open } \\
\text { by default policy }\end{array}$ & $\begin{array}{l}\text { Q.2. At the central/federal level, are there formal requirements } \\
\text { whereby government data should be "open by default" (unless a } \\
\text { legitimate justification is provided)? }\end{array}$ & Yes/No & 1.a \\
\hline 2 & Data availability & $\begin{array}{l}\text { Content of the open by } \\
\text { default policy }\end{array}$ & $\begin{array}{l}\text { Clear identification of } \\
\text { legitimate exceptions to } \\
\text { the open by default rule }\end{array}$ & $\begin{array}{l}\text { Q.3.b. Is there a list of legitimate justifications for not releasing some } \\
\text { data publicly which is available online to the public? }\end{array}$ & Yes/No & 1.b \\
\hline 3 & Data availability & $\begin{array}{l}\text { Content of the open by } \\
\text { default policy }\end{array}$ & $\begin{array}{l}\text { Compliance with } \\
\text { privacy legislation }\end{array}$ & $\begin{array}{l}\text { Q.20. At the central/federal level, are there formal requirements to } \\
\text { anonymize data before any public release? }\end{array}$ & Yes/No & $1 . f$ \\
\hline 4 & Data availability & $\begin{array}{l}\text { Content of the open by } \\
\text { default policy }\end{array}$ & $\begin{array}{l}\text { Compliance with } \\
\text { privacy legislation }\end{array}$ & $\begin{array}{l}\text { Q.17. Since January 2012, has/have any assessment(s) (e.g. through } \\
\text { the form of a report) been undertaken for the whole central/federal } \\
\text { government to ensure that government data made publicly available } \\
\text { respect national norms/standards in terms of: Security, Confidentiality, } \\
\text { Privacy, Intellectual Property. }\end{array}$ & Yes/No & 1.e, $1 . f$ \\
\hline 5 & Data availability & $\begin{array}{l}\text { Content of the open by } \\
\text { default policy }\end{array}$ & $\begin{array}{l}\text { Compliance with } \\
\text { privacy legislation }\end{array}$ & Q.17.a. Has this assessment(s) been made available online? & Yes/No & 1.e, $1 . f$ \\
\hline 6 & Data availability & $\begin{array}{l}\text { Content of the open by } \\
\text { default policy }\end{array}$ & $\begin{array}{l}\text { Compliance with } \\
\text { privacy legislation }\end{array}$ & $\begin{array}{l}\text { Q.19. Since January 2012, has/have any assessment(s) (e.g. through } \\
\text { the form of a report) been undertaken for the whole central/federal } \\
\text { government to evaluate whether all relevant legislation/regulations on } \\
\text { open government data are currently in place with regards to: Security, } \\
\text { Privacy, Confidentiality, Intellectual Property. }\end{array}$ & Yes/No & 1.e, $1 . f$ \\
\hline 7 & Data availability & $\begin{array}{l}\text { Content of the open by } \\
\text { default policy }\end{array}$ & $\begin{array}{l}\text { Performance incentives } \\
\text { for public officials }\end{array}$ & $\begin{array}{l}\text { Q.62. To what extent is the implementation of open government data } \\
\text { requirements (e.g. regarding timeliness of data sharing, use of open } \\
\text { formats) considered as part of performance indicators of } \\
\text { organisations? }\end{array}$ & $\begin{array}{l}\text { In no central/federal } \\
\text { agency/ministry }(0), \text { Rarely } \\
(0.25) \text {, Sometimes }(0.75) \\
\text { Often }(1)\end{array}$ & 1.d \\
\hline 8 & Data availability & $\begin{array}{l}\text { Content of the open by } \\
\text { default policy }\end{array}$ & $\begin{array}{l}\text { Performance incentives } \\
\text { for public officials }\end{array}$ & $\begin{array}{l}\text { Q.61. Are there formal incentives provided to civil servants to } \\
\text { encourage reuse of open government data in the policy development } \\
\text { process? }\end{array}$ & Yes/No & 1.d \\
\hline
\end{tabular}




\begin{tabular}{|c|c|c|c|c|c|c|}
\hline 9 & Data availability & $\begin{array}{l}\text { Stakeholder } \\
\text { engagement for data } \\
\text { release }\end{array}$ & $\begin{array}{l}\text { Existence of formal } \\
\text { requirements to consult } \\
\text { stakeholders for data } \\
\text { release }\end{array}$ & $\begin{array}{l}\text { Q.23. Are there formal requirements for central/federal } \\
\text { Ministries/agencies to regularly conduct consultations with users to } \\
\text { inform open data plans? }\end{array}$ & Yes/No & 2.b \\
\hline 10 & Data availability & $\begin{array}{l}\text { Stakeholder } \\
\text { engagement for data } \\
\text { release }\end{array}$ & $\begin{array}{l}\text { Existence of formal } \\
\text { requirements to consult } \\
\text { stakeholders for data } \\
\text { release }\end{array}$ & $\begin{array}{l}\text { Q.24. Are the following elements in place to supportive effective } \\
\text { consultations with users on open government data plans? Written } \\
\text { guidance on how to conduct consultations with data users }\end{array}$ & Yes/No & 2.a \\
\hline 11 & Data availability & $\begin{array}{l}\text { Stakeholder } \\
\text { engagement for data } \\
\text { release }\end{array}$ & $\begin{array}{l}\text { Existence of formal } \\
\text { requirements to consult } \\
\text { stakeholders for data } \\
\text { release }\end{array}$ & $\begin{array}{l}\text { Q.24. Are the following elements in place to supportive effective } \\
\text { consultations with users on open government data plans? Formal } \\
\text { requirements to provide certain documents (e.g. comprehensive list of } \\
\text { data holdings) when conducting user consultations }\end{array}$ & Yes/No & 2.a \\
\hline 12 & Data availability & $\begin{array}{l}\text { Stakeholder } \\
\text { engagement for data } \\
\text { release }\end{array}$ & $\begin{array}{l}\text { Existence of formal } \\
\text { requirements to consult } \\
\text { stakeholders for data } \\
\text { release }\end{array}$ & $\begin{array}{l}\text { Q.24. Are the following elements in place to supportive effective } \\
\text { consultations with users on open government data plans? Formal } \\
\text { requirements regarding minimum periods for responding to a } \\
\text { government consultations on open government data }\end{array}$ & Yes/No & 2.a \\
\hline 13 & Data availability & $\begin{array}{l}\text { Stakeholder } \\
\text { engagement for data } \\
\text { release }\end{array}$ & $\begin{array}{l}\text { Existence of formal } \\
\text { requirements to consult } \\
\text { stakeholders for data } \\
\text { release }\end{array}$ & $\begin{array}{l}\text { Q.24. Are the following elements in place to supportive effective } \\
\text { consultations with users on open government data plans? Formal } \\
\text { requirements to systematically publish online the results of } \\
\text { consultations with users. }\end{array}$ & Yes/No & 2.a \\
\hline 14 & Data availability & $\begin{array}{l}\text { Stakeholder } \\
\text { engagement for data } \\
\text { release }\end{array}$ & $\begin{array}{l}\text { Existence of formal } \\
\text { requirements to consult } \\
\text { stakeholders for data } \\
\text { release }\end{array}$ & $\begin{array}{l}\text { Q.28. In practice, are the results from users' consultations conducted } \\
\text { by ministries/agencies on open data plans (prioritization, publication, or } \\
\text { data release dates) released online? }\end{array}$ & Yes/No & 2.a \\
\hline 15 & Data availability & $\begin{array}{l}\text { Stakeholder } \\
\text { engagement for data } \\
\text { release }\end{array}$ & $\begin{array}{l}\text { Existence of formal } \\
\text { requirements to consult } \\
\text { stakeholders for data } \\
\text { release }\end{array}$ & $\begin{array}{l}\text { Q.29. Does the central/federal government keep track of the } \\
\text { number/percentage of data users that respond to formal consultations? }\end{array}$ & Yes/No & 2.a \\
\hline 16 & Data availability & $\begin{array}{l}\text { Stakeholder } \\
\text { engagement for data } \\
\text { release }\end{array}$ & $\begin{array}{l}\text { Requirements to } \\
\text { maintain lists of data } \\
\text { holdings in each } \\
\text { ministries/agencies to } \\
\text { support effective } \\
\text { consultations }\end{array}$ & $\begin{array}{l}\text { Q.12. At the central/federal level, are there formal requirements for } \\
\text { ministries/agencies to maintain a list of data holdings (e.g. data } \\
\text { catalog)? }\end{array}$ & Yes/No & 2.a \\
\hline 17 & Data availability & $\begin{array}{l}\text { Stakeholder } \\
\text { engagement for data } \\
\text { release }\end{array}$ & $\begin{array}{l}\text { Requirements to } \\
\text { maintain lists of data } \\
\text { holdings in each } \\
\text { ministries/agencies to } \\
\text { support effective } \\
\text { consultations }\end{array}$ & $\begin{array}{l}\text { Q.13. Is there a central/federal body with responsibilities for ensuring } \\
\text { that these lists of data are maintained by central/federal line ministries } \\
\text { and agencies in practice? }\end{array}$ & Yes/No & 2.a \\
\hline
\end{tabular}


Stakeholder engagement for data release
Frequency of stakeholder consultations on open data plans

Q.27. In practice, since January 2015 , how many times were the ollowing groups of users consulted to inform open data plans of the whole central/federal government? (this question excludes ad hoc comments' transmissions from users for instance through feedback sections in government portals): Private sector organizations (e.g.

$$
\text { businesses). }
$$

.27. In practice, since January 2015 , how many times were the following groups of users consulted to inform open data plans of the whole central/federal government? (this question excludes ad hoc comments' transmissions from users for instance through feedback sections in government portals): Citizens, civil society organizations, journalists, academia

Frequency of consultations on open data plans

Q.27. In practice, since January 2015 , how many times were the

Frequency of

Stakeholder

20 Data availability

engagement for data

release

21 Data availability Implementation $\quad \begin{gathered}\text { Number of datasets } \\ \text { made available on the } \\ \text { central/federal data } \\ \text { portal }\end{gathered} \quad \begin{gathered}\text { Q.67. On the central/federal one stop shop portal how many datasets } \\ \text { are currently available (as of 1st of October 2016 or latest available)?: } \\ \text { Tabular data }\end{gathered}$

mplementation

Never (0), rarely $(0.25)$ sometimes $(0.75)$, often (1)

Data availability

stakeholder

consultations on open

data plans whole central/federal government? (this question excludes ad hoc comments' transmissions from users for instance through feedback sections in government portals): Civil servants

Availability of high

Q.68. On the federal/central government "one-stop-shop" portal are the following data publicly available (either directly or indirectly)? (please provide systematically one web link): Company/business register. value datasets Availability of high Q.68. On the federal/central government "one-stop-shop" portal are the value datasets

$$
\text { provide systematically one web link): Crime statistics }
$$

Never (0), rarely $(0.25)$ sometimes $(0.75)$, often (1)

\section{Outliers (1 and 0). Middle}

categories: score normalized based on difference with the mean: More than $75 \%$ above the mean $=0.75$; less than $75 \%$ above or below the mean $=0.5 ; 75 \%$ below the mean $=$

$$
0.25 \text {. }
$$

1.a, 3.a

G8 Open

0.018867925 Data Charter - Action 2

G8 Open - Action 2 Availability of high Q.68. On the federal/central government "one-stop-shop" portal are the value datasets provide systematically one web link): Safety

G8 Open

Data Charter - Action 2

Q.68. On the federal/central government "one-stop-shop" portal are the following data publicly available (either directly or indirectly)? (please provide systematically one web link): Meteorological/weather

${ }^{5}$ Each individual dataset was attributed a score of 0.018867925 . The sum of all datasets in Question 68 is therefore equal to 1 . That is, if all datasets indicated in Question 68 are available on the central/federal open government data one-stop-shop portal, a country would have a total score of 1 for Question 68 

data publicly available (either directly or indirectly)?
provide systematically one web link): Agriculture

27 Data availability

Implementation

Availability of high value datasets

28 Data availability

Implementation

Availability of high value datasets

\begin{tabular}{|c|c|c|c|}
\hline 29 & Data availability & Implementation & $\begin{array}{l}\text { Availability of high } \\
\text { value datasets }\end{array}$ \\
\hline 30 & Data availability & Implementation & $\begin{array}{l}\text { Availability of high } \\
\text { value datasets }\end{array}$ \\
\hline 31 & Data availability & Implementation & $\begin{array}{l}\text { Availability of high } \\
\text { value datasets }\end{array}$ \\
\hline 32 & Data availability & Implementation & $\begin{array}{l}\text { Availability of high } \\
\text { value datasets }\end{array}$ \\
\hline 33 & Data availability & Implementation & $\begin{array}{l}\text { Availability of high } \\
\text { value datasets }\end{array}$ \\
\hline 34 & Data availability & Implementation & $\begin{array}{l}\text { Availability of high } \\
\text { value datasets }\end{array}$ \\
\hline 35 & Data availability & Implementation & $\begin{array}{l}\text { Availability of high } \\
\text { value datasets }\end{array}$ \\
\hline 36 & Data availability & Implementation & $\begin{array}{l}\text { Availability of high } \\
\text { value datasets }\end{array}$ \\
\hline 37 & Data availability & Implementation & $\begin{array}{l}\text { Availability of high } \\
\text { value datasets }\end{array}$ \\
\hline 38 & Data availability & Implementation & $\begin{array}{l}\text { Availability of high } \\
\text { value datasets }\end{array}$ \\
\hline
\end{tabular}

Q.68. On the federal/central government "one-stop-shop" portal are the following data publicly available (either directly or indirectly)? (please provide systematically one web link): Forestry

Q.68. On the federal/central government "one-stop-shop" portal are the following data publicly available (either directly or indirectly)? (please provide systematically one web link): Fishing

Q.68. On the federal/central government "one-stop-shop" portal are the following data publicly available (either directly or indirectly)? (please provide systematically one web link): Hunting

Q.68. On the federal/central government "one-stop-shop" portal are the following data publicly available (either directly or indirectly)? (please provide systematically one web link): List of schools

Q.68. On the federal/central government "one-stop-shop" portal are the ollowing data publicly available (either directly or indirectly)? (please provide systematically one web link): Performance of schools

Q.68. On the federal/central government "one-stop-shop" portal are the following data publicly available (either directly or indirectly)? (please provide systematically one web link): Digital skills.

Q.68. On the federal/central government "one-stop-shop" portal are the following data publicly available (either directly or indirectly)? (please provide systematically one web link): Pollution levels.

Q.68. On the federal/central government "one-stop-shop" portal are the following data publicly available (either directly or indirectly)? (please provide systematically one web link): Energy consumption.

Q.68. On the federal/central government "one-stop-shop" portal are the following data publicly available (either directly or indirectly)? (please provide systematically one web link): Transaction spend.

Q.68. On the federal/central government "one-stop-shop" portal are the following data publicly available (either directly or indirectly)? (please provide systematically one web link): Contracts let

Q.68. On the federal/central government "one-stop-shop" portal are the following data publicly available (either directly or indirectly)? (please provide systematically one web link): Call for tender.

Q.68. On the federal/central government "one-stop-shop" portal are the following data publicly available (either directly or indirectly)? (please provide systematically one web link): Future tenders.
0.018867925

G8 Open

Data Charter - Action 2

G8 Open

ata Charter

0.018867925

- Action 2

G8 Open

Data Charter

- Action 2

G8 Open

Data Charter

- Action 2

G8 Open

Data Charter - Action 2

0.018867925 Data Charter

G8

- Action 2

G8 Open

Data Charter

- Action 2

G8 Open

$0.018867925 \quad \begin{aligned} & \text { Data Charte } \\ & \text { - Action } 2\end{aligned}$

$0.018867925 \quad \begin{aligned} & \text { Data Charte } \\ & \text { - Action } 2\end{aligned}$

G8 Open

$0.018867925 \quad \begin{gathered}\text { Data Charter } \\ \text { - Action } 2\end{gathered}$
Acs

G8 Open

ata Charte - Action 2

G8 Open

Data Charte - Action 2

G8 Open

ata Charter

- Action 2

0.018867925 - Action 2

$0.018867925 \quad$ G8 Open

- Action 2 


\begin{tabular}{|c|c|c|c|c|c|c|}
\hline 39 & Data availability & Implementation & $\begin{array}{l}\text { Availability of high } \\
\text { value datasets }\end{array}$ & $\begin{array}{l}\text { Q.68. On the federal/central government "one-stop-shop" portal are the } \\
\text { following data publicly available (either directly or indirectly)? (please } \\
\text { provide systematically one web link): Local budget. }\end{array}$ & 0.018867925 & $\begin{array}{l}\text { G8 Open } \\
\text { Data Charter } \\
\text { - Action } 2\end{array}$ \\
\hline 40 & Data availability & Implementation & $\begin{array}{l}\text { Availability of high } \\
\text { value datasets }\end{array}$ & $\begin{array}{l}\text { Q.68. On the federal/central government "one-stop-shop" portal are the } \\
\text { following data publicly available (either directly or indirectly)? (please } \\
\text { provide systematically one web link): National budget planned. }\end{array}$ & 0.018867925 & $\begin{array}{l}\text { G8 Open } \\
\text { Data Charter } \\
\text { - Action } 2\end{array}$ \\
\hline 41 & Data availability & Implementation & $\begin{array}{l}\text { Availability of high } \\
\text { value datasets }\end{array}$ & $\begin{array}{l}\text { Q.68. On the federal/central government "one-stop-shop" portal are the } \\
\text { following data publicly available (either directly or indirectly)? (please } \\
\text { provide systematically one web link): National budget spent. }\end{array}$ & 0.018867925 & $\begin{array}{l}\text { G8 Open } \\
\text { Data Charter } \\
\text { - Action } 2\end{array}$ \\
\hline 42 & Data availability & Implementation & $\begin{array}{l}\text { Availability of high } \\
\text { value datasets }\end{array}$ & $\begin{array}{l}\text { Q.68. On the federal/central government "one-stop-shop" portal are the } \\
\text { following data publicly available (either directly or indirectly)? (please } \\
\text { provide systematically one web link): Zipcodes/Postcodes. }\end{array}$ & 0.018867925 & $\begin{array}{l}\text { G8 Open } \\
\text { Data Charter } \\
\text { - Action } 2\end{array}$ \\
\hline 43 & Data availability & Implementation & $\begin{array}{l}\text { Availability of high } \\
\text { value datasets }\end{array}$ & $\begin{array}{l}\text { Q.68. On the federal/central government "one-stop-shop" portal are the } \\
\text { following data publicly available (either directly or indirectly)? (please } \\
\text { provide systematically one web link): National maps. }\end{array}$ & 0.018867925 & $\begin{array}{l}\text { G8 Open } \\
\text { Data Charter } \\
\text { - Action } 2\end{array}$ \\
\hline 44 & Data availability & Implementation & $\begin{array}{l}\text { Availability of high } \\
\text { value datasets }\end{array}$ & $\begin{array}{l}\text { Q.68. On the federal/central government "one-stop-shop" portal are the } \\
\text { following data publicly available (either directly or indirectly)? (please } \\
\text { provide systematically one web link): Local maps. }\end{array}$ & 0.018867925 & $\begin{array}{l}\text { G8 Open } \\
\text { Data Charter } \\
\text { - Action } 2\end{array}$ \\
\hline 45 & Data availability & Implementation & $\begin{array}{l}\text { Availability of high } \\
\text { value datasets }\end{array}$ & $\begin{array}{l}\text { Q.68. On the federal/central government "one-stop-shop" portal are the } \\
\text { following data publicly available (either directly or indirectly)? (please } \\
\text { provide systematically one web link): Aid. }\end{array}$ & 0.018867925 & $\begin{array}{l}\text { G8 Open } \\
\text { Data Charter } \\
\text { - Action } 2\end{array}$ \\
\hline 46 & Data availability & Implementation & $\begin{array}{l}\text { Availability of high } \\
\text { value datasets }\end{array}$ & $\begin{array}{l}\text { Q.68. On the federal/central government "one-stop-shop" portal are the } \\
\text { following data publicly available (either directly or indirectly)? (please } \\
\text { provide systematically one web link) - Food security. }\end{array}$ & 0.018867925 & $\begin{array}{l}\text { G8 Open } \\
\text { Data Charter } \\
\text { - Action } 2\end{array}$ \\
\hline 47 & Data availability & Implementation & $\begin{array}{l}\text { Availability of high } \\
\text { value datasets }\end{array}$ & $\begin{array}{l}\text { Q.68. On the federal/central government "one-stop-shop" portal are the } \\
\text { following data publicly available (either directly or indirectly)? (please } \\
\text { provide systematically one web link): Extractives. }\end{array}$ & 0.018867925 & $\begin{array}{l}\text { G8 Open } \\
\text { Data Charter } \\
\text { - Action } 2\end{array}$ \\
\hline 48 & Data availability & Implementation & $\begin{array}{l}\text { Availability of high } \\
\text { value datasets }\end{array}$ & $\begin{array}{l}\text { Q.68. On the federal/central government "one-stop-shop" portal are the } \\
\text { following data publicly available (either directly or indirectly)? (please } \\
\text { provide systematically one web link): Land. }\end{array}$ & 0.018867925 & $\begin{array}{l}\text { G8 Open } \\
\text { Data Charter } \\
\text { - Action } 2\end{array}$ \\
\hline 49 & Data availability & Implementation & $\begin{array}{l}\text { Availability of high } \\
\text { value datasets }\end{array}$ & $\begin{array}{l}\text { Q.68. On the federal/central government "one-stop-shop" portal are the } \\
\text { following data publicly available (either directly or indirectly)? (please } \\
\text { provide systematically one web link): Government contact points. }\end{array}$ & 0.018867925 & $\begin{array}{l}\text { G8 Open } \\
\text { Data Charter } \\
\text { - Action } 2\end{array}$ \\
\hline 50 & Data availability & Implementation & $\begin{array}{l}\text { Availability of high } \\
\text { value datasets }\end{array}$ & $\begin{array}{l}\text { Q.68. On the federal/central government "one-stop-shop" portal are the } \\
\text { following data publicly available (either directly or indirectly)? (please } \\
\text { provide systematically one web link): Election results. }\end{array}$ & 0.018867925 & $\begin{array}{l}\text { G8 Open } \\
\text { Data Charter } \\
\text { - Action } 2\end{array}$ \\
\hline 51 & Data availability & Implementation & $\begin{array}{l}\text { Availability of high } \\
\text { value datasets }\end{array}$ & $\begin{array}{l}\text { Q.68. On the federal/central government "one-stop-shop" portal are the } \\
\text { following data publicly available (either directly or indirectly)? (please } \\
\text { provide systematically one web link): Legislation and statutes. }\end{array}$ & 0.018867925 & $\begin{array}{l}\text { G8 Open } \\
\text { Data Charter } \\
\text { - Action } 2\end{array}$ \\
\hline
\end{tabular}




\begin{tabular}{|c|c|c|c|c|c|c|}
\hline 52 & Data availability & Implementation & $\begin{array}{l}\text { Availability of high } \\
\text { value datasets }\end{array}$ & $\begin{array}{l}\text { Q.68. On the federal/central government "one-stop-shop" portal are the } \\
\text { following data publicly available (either directly or indirectly)? (please } \\
\text { provide systematically one web link): Salaries (pay scales). }\end{array}$ & 0.018867925 & $\begin{array}{l}\text { G8 Open } \\
\text { Data Charter } \\
\text { - Action } 2\end{array}$ \\
\hline 53 & Data availability & Implementation & $\begin{array}{l}\text { Availability of high } \\
\text { value datasets }\end{array}$ & $\begin{array}{l}\text { Q.68. On the federal/central government "one-stop-shop" portal are the } \\
\text { following data publicly available (either directly or indirectly)? (please } \\
\text { provide systematically one web link): Hospitality/gifts. }\end{array}$ & 0.018867925 & $\begin{array}{l}\text { G8 Open } \\
\text { Data Charter } \\
\text { - Action } 2\end{array}$ \\
\hline 54 & Data availability & Implementation & $\begin{array}{l}\text { Availability of high } \\
\text { value datasets }\end{array}$ & $\begin{array}{l}\text { Q.68. On the federal/central government "one-stop-shop" portal are the } \\
\text { following data publicly available (either directly or indirectly)? (please } \\
\text { provide systematically one web link): Prescription data. }\end{array}$ & 0.018867925 & $\begin{array}{l}\text { G8 Open } \\
\text { Data Charter } \\
\text { - Action } 2\end{array}$ \\
\hline 55 & Data availability & Implementation & $\begin{array}{l}\text { Availability of high } \\
\text { value datasets }\end{array}$ & $\begin{array}{l}\text { Q.68. On the federal/central government "one-stop-shop" portal are the } \\
\text { following data publicly available (either directly or indirectly)? (please } \\
\text { provide systematically one web link): Performance data (health } \\
\text { system). }\end{array}$ & 0.018867925 & $\begin{array}{l}\text { G8 Open } \\
\text { Data Charter } \\
\text { - Action } 2\end{array}$ \\
\hline 56 & Data availability & Implementation & $\begin{array}{l}\text { Availability of high } \\
\text { value datasets }\end{array}$ & $\begin{array}{l}\text { Q.68. On the federal/central government "one-stop-shop" portal are the } \\
\text { following data publicly available (either directly or indirectly)? (please } \\
\text { provide systematically one web link): Genome data. }\end{array}$ & 0.018867925 & $\begin{array}{l}\text { G8 Open } \\
\text { Data Charter } \\
\text { - Action } 2\end{array}$ \\
\hline 57 & Data availability & Implementation & $\begin{array}{l}\text { Availability of high } \\
\text { value datasets }\end{array}$ & $\begin{array}{l}\text { Q.68. On the federal/central government "one-stop-shop" portal are the } \\
\text { following data publicly available (either directly or indirectly)? (please } \\
\text { provide systematically one web link): Research and educational } \\
\text { activity. }\end{array}$ & 0.018867925 & $\begin{array}{l}\text { G8 Open } \\
\text { Data Charter } \\
\text { - Action } 2\end{array}$ \\
\hline 58 & Data availability & Implementation & $\begin{array}{l}\text { Availability of high } \\
\text { value datasets }\end{array}$ & $\begin{array}{l}\text { Q.68. On the federal/central government "one-stop-shop" portal are the } \\
\text { following data publicly available (either directly or indirectly)? (please } \\
\text { provide systematically one web link): Experiment results. }\end{array}$ & 0.018867925 & $\begin{array}{l}\text { G8 Open } \\
\text { Data Charter } \\
\text { - Action } 2\end{array}$ \\
\hline 59 & Data availability & Implementation & $\begin{array}{l}\text { Availability of high } \\
\text { value datasets }\end{array}$ & $\begin{array}{l}\text { Q.68. On the federal/central government "one-stop-shop" portal are the } \\
\text { following data publicly available (either directly or indirectly)? (please } \\
\text { provide systematically one web link): National Statistics. }\end{array}$ & 0.018867925 & $\begin{array}{l}\text { G8 Open } \\
\text { Data Charter } \\
\text { - Action } 2\end{array}$ \\
\hline 60 & Data availability & Implementation & $\begin{array}{l}\text { Availability of high } \\
\text { value datasets }\end{array}$ & $\begin{array}{l}\text { Q.68. On the federal/central government "one-stop-shop" portal are the } \\
\text { following data publicly available (either directly or indirectly)? (please } \\
\text { provide systematically one web link): Census. }\end{array}$ & 0.018867925 & $\begin{array}{l}\text { G8 Open } \\
\text { Data Charter } \\
\text { - Action } 2\end{array}$ \\
\hline 61 & Data availability & Implementation & $\begin{array}{l}\text { Availability of high } \\
\text { value datasets }\end{array}$ & $\begin{array}{l}\text { Q.68. On the federal/central government "one-stop-shop" portal are the } \\
\text { following data publicly available (either directly or indirectly)? (please } \\
\text { provide systematically one web link): Infrastructure. }\end{array}$ & 0.018867925 & $\begin{array}{l}\text { G8 Open } \\
\text { Data Charter } \\
\text { - Action } 2\end{array}$ \\
\hline 62 & Data availability & Implementation & $\begin{array}{l}\text { Availability of high } \\
\text { value datasets }\end{array}$ & $\begin{array}{l}\text { Q.68. On the federal/central government "one-stop-shop" portal are the } \\
\text { following data publicly available (either directly or indirectly)? (please } \\
\text { provide systematically one web link): Wealth. }\end{array}$ & 0.018867925 & $\begin{array}{l}\text { G8 Open } \\
\text { Data Charter } \\
\text { - Action } 2\end{array}$ \\
\hline
\end{tabular}




\begin{tabular}{|c|c|c|c|c|c|c|}
\hline 63 & Data availability & Implementation & $\begin{array}{l}\text { Availability of high } \\
\text { value datasets }\end{array}$ & $\begin{array}{l}\text { Q.68. On the federal/central government "one-stop-shop" portal are the } \\
\text { following data publicly available (either directly or indirectly)? (please } \\
\text { provide systematically one web link): Skills. }\end{array}$ & 0.018867925 & $\begin{array}{l}\text { G8 Open } \\
\text { Data Charter } \\
\text { - Action } 2\end{array}$ \\
\hline 64 & Data availability & Implementation & $\begin{array}{l}\text { Availability of high } \\
\text { value datasets }\end{array}$ & $\begin{array}{l}\text { Q.68. On the federal/central government "one-stop-shop" portal are the } \\
\text { following data publicly available (either directly or indirectly)? (please } \\
\text { provide systematically one web link): Housing. }\end{array}$ & 0.018867925 & $\begin{array}{l}\text { G8 Open } \\
\text { Data Charter } \\
\text { - Action } 2\end{array}$ \\
\hline 65 & Data availability & Implementation & $\begin{array}{l}\text { Availability of high } \\
\text { value datasets }\end{array}$ & $\begin{array}{l}\text { Q.68. On the federal/central government "one-stop-shop" portal are the } \\
\text { following data publicly available (either directly or indirectly)? (please } \\
\text { provide systematically one web link): Health insurance and } \\
\text { unemployment benefits. }\end{array}$ & 0.018867925 & $\begin{array}{l}\text { G8 Open } \\
\text { Data Charter } \\
\text { - Action } 2\end{array}$ \\
\hline 66 & Data availability & Implementation & $\begin{array}{l}\text { Availability of high } \\
\text { value datasets }\end{array}$ & $\begin{array}{l}\text { Q.68. On the federal/central government "one-stop-shop" portal are the } \\
\text { following data publicly available (either directly or indirectly)? (please } \\
\text { provide systematically one web link): Ageing society. }\end{array}$ & 0.018867925 & $\begin{array}{l}\text { G8 Open } \\
\text { Data Charter } \\
\text { - Action } 2\end{array}$ \\
\hline 67 & Data availability & Implementation & $\begin{array}{l}\text { Availability of high } \\
\text { value datasets }\end{array}$ & $\begin{array}{l}\text { Q.68. On the federal/central government "one-stop-shop" portal are the } \\
\text { following data publicly available (either directly or indirectly)? (please } \\
\text { provide systematically one web link): Public transport timetables. }\end{array}$ & 0.018867925 & $\begin{array}{l}\text { G8 Open } \\
\text { Data Charter } \\
\text { - Action } 2\end{array}$ \\
\hline 68 & Data availability & Implementation & $\begin{array}{l}\text { Availability of high } \\
\text { value datasets }\end{array}$ & $\begin{array}{l}\text { Q.68. On the federal/central government "one-stop-shop" portal are the } \\
\text { following data publicly available (either directly or indirectly)? (please } \\
\text { provide systematically one web link): Broadband penetration. }\end{array}$ & 0.018867925 & $\begin{array}{l}\text { G8 Open } \\
\text { Data Charter } \\
\text { - Action } 2\end{array}$ \\
\hline 69 & Data availability & Implementation & $\begin{array}{l}\text { Availability of high } \\
\text { value datasets }\end{array}$ & $\begin{array}{l}\text { Q.68. On the federal/central government "one-stop-shop" portal are the } \\
\text { following data publicly available (either directly or indirectly)? (please } \\
\text { provide systematically one web link): Motor vehicle registration } \\
\text { statistics. }\end{array}$ & 0.018867925 & $\begin{array}{l}\text { G8 Open } \\
\text { Data Charter } \\
\text { - Action } 2\end{array}$ \\
\hline 70 & Data availability & Implementation & $\begin{array}{l}\text { Availability of high } \\
\text { value datasets }\end{array}$ & $\begin{array}{l}\text { Q.68. On the federal/central government "one-stop-shop" portal are the } \\
\text { following data publicly available (either directly or indirectly)? (please } \\
\text { provide systematically one web link): Beneficial ownership. }\end{array}$ & 0.018867925 & $\begin{array}{l}\text { G8 Open } \\
\text { Data Charter } \\
\text { - Action } 2\end{array}$ \\
\hline 71 & Data availability & Implementation & $\begin{array}{l}\text { Availability of high } \\
\text { value datasets }\end{array}$ & $\begin{array}{l}\text { Q.68. On the federal/central government "one-stop-shop" portal are the } \\
\text { following data publicly available (either directly or indirectly)? (please } \\
\text { provide systematically one web link): Lobbying meetings. }\end{array}$ & 0.018867925 & $\begin{array}{l}\text { G8 Open } \\
\text { Data Charter } \\
\text { - Action 2, } \\
\text { 5.b. }\end{array}$ \\
\hline 72 & Data availability & Implementation & $\begin{array}{l}\text { Availability of high } \\
\text { value datasets }\end{array}$ & $\begin{array}{l}\text { Q.68. On the federal/central government "one-stop-shop" portal are the } \\
\text { following data publicly available (either directly or indirectly)? (please } \\
\text { provide systematically one web link): Declarations of interest. }\end{array}$ & 0.018867925 & $\begin{array}{l}\text { G8 Open } \\
\text { Data Charter } \\
\text { - Action 2, } \\
\text { 5.b. }\end{array}$ \\
\hline 73 & Data availability & Implementation & $\begin{array}{l}\text { Availability of high } \\
\text { value datasets }\end{array}$ & $\begin{array}{l}\text { Q.68. On the federal/central government "one-stop-shop" portal are the } \\
\text { following data publicly available (either directly or indirectly)? (please } \\
\text { provide systematically one web link): Risk management. }\end{array}$ & 0.018867925 & $\begin{array}{l}\text { G8 Open } \\
\text { Data Charter } \\
\text { - Action } 2\end{array}$ \\
\hline
\end{tabular}




\section{Pillar 2 - Data accessibility}

\begin{tabular}{|c|c|c|c|c|c|c|}
\hline $\mathbf{N}^{\circ}$ & Pillar & Sub-pillar & Parameter & Variable & Response options & $\begin{array}{c}\text { IODC } \\
\text { principle }\end{array}$ \\
\hline 1 & Data accessibility & $\begin{array}{l}\text { Content of the free and } \\
\text { open access to data policy }\end{array}$ & $\begin{array}{l}\text { Existence of requirements on } \\
\text { open license, formats and } \\
\text { metadata }\end{array}$ & $\begin{array}{l}\text { Q.31. At the central/federal government are there formal } \\
\text { requirements for line ministries/agencies to provide } \\
\text { government data: With an open license. }\end{array}$ & Yes/No & 3.c \\
\hline 2 & Data accessibility & $\begin{array}{l}\text { Content of the free and } \\
\text { open access to data policy }\end{array}$ & $\begin{array}{l}\text { Existence of requirements on } \\
\text { open license, formats and } \\
\text { metadata }\end{array}$ & $\begin{array}{l}\text { Q.33. Do the existing requirements to provide government } \\
\text { data with an open license allow users to carry out the } \\
\text { following actions with the data: Access/Download }\end{array}$ & Yes/No & $3 . c$ \\
\hline 3 & Data accessibility & $\begin{array}{l}\text { Content of the free and } \\
\text { open access to data policy }\end{array}$ & $\begin{array}{l}\text { Existence of requirements on } \\
\text { open license, formats and } \\
\text { metadata }\end{array}$ & $\begin{array}{l}\text { Q.33. Do the existing requirements to provide government } \\
\text { data with an open license allow users to carry out the } \\
\text { following actions with the data: Copy/Use }\end{array}$ & Yes/No & 3.c \\
\hline 4 & Data accessibility & $\begin{array}{l}\text { Content of the free and } \\
\text { open access to data policy }\end{array}$ & $\begin{array}{l}\text { Existence of requirements on } \\
\text { open license, formats and } \\
\text { metadata }\end{array}$ & $\begin{array}{l}\text { Q.36. At the central/federal government are there formal } \\
\text { requirements for line ministries/agencies to provide data: In } \\
\text { machine readable format. }\end{array}$ & Yes/No & 3.b \\
\hline 5 & Data accessibility & $\begin{array}{l}\text { Content of the free and } \\
\text { open access to data policy }\end{array}$ & $\begin{array}{l}\text { Existence of requirements on } \\
\text { open license, formats and } \\
\text { metadata }\end{array}$ & $\begin{array}{l}\text { Q.36. At the central/federal government are there formal } \\
\text { requirements for line ministries/agencies to provide data: } \\
\text { With their associated metadata. }\end{array}$ & Yes/No & 4.b \\
\hline 6 & Data accessibility & $\begin{array}{l}\text { Content of the free and } \\
\text { open access to data policy }\end{array}$ & $\begin{array}{l}\text { Existence of requirements to } \\
\text { provide access to data free } \\
\text { of charge }\end{array}$ & $\begin{array}{l}\text { Q.31. At the central/federal government are there formal } \\
\text { requirements for line ministries/agencies to provide } \\
\text { government data: Free of charge. }\end{array}$ & Yes/No & 3.c \\
\hline 7 & Data accessibility & $\begin{array}{l}\text { Content of the free and } \\
\text { open access to data policy }\end{array}$ & $\begin{array}{l}\text { Existence of requirements to } \\
\text { provide access to data free } \\
\text { of charge }\end{array}$ & $\begin{array}{l}\text { Q.32. Do the existing requirements to provide government } \\
\text { data free of charge allow users to carry out the following } \\
\text { actions with the data: Download and copy. }\end{array}$ & Yes/No & 3.c \\
\hline 8 & Data accessibility & $\begin{array}{l}\text { Content of the free and } \\
\text { open access to data policy }\end{array}$ & $\begin{array}{l}\text { Existence of requirements to } \\
\text { provide access to data free } \\
\text { of charge }\end{array}$ & $\begin{array}{l}\text { Q.32. Do the existing requirements to provide government } \\
\text { data free of charge allow users to carry out the following } \\
\text { actions with the data: Use. }\end{array}$ & Yes/No & 3.c \\
\hline 9 & Data accessibility & $\begin{array}{l}\text { Content of the free and } \\
\text { open access to data policy }\end{array}$ & $\begin{array}{l}\text { Existence of requirements to } \\
\text { provide timely access to } \\
\text { disaggregated data }\end{array}$ & $\begin{array}{c}\text { Q.5. At the central/federal level, are there formal } \\
\text { requirements to publish data in a disaggregated way when } \\
\text { applicable? }\end{array}$ & Yes/No & 2.d \\
\hline 10 & Data accessibility & $\begin{array}{l}\text { Content of the free and } \\
\text { open access to data policy }\end{array}$ & $\begin{array}{l}\text { Existence of requirements to } \\
\text { provide timely access to } \\
\text { disaggregated data }\end{array}$ & $\begin{array}{l}\text { Q.38. At the central/federal level are there formal } \\
\text { requirements to: Provide data in a timely manner, without } \\
\text { undue delay. }\end{array}$ & Yes/No & 2.b \\
\hline
\end{tabular}




\begin{tabular}{|c|c|c|c|c|c|c|}
\hline 11 & Data accessibility & $\begin{array}{l}\text { Stakeholder engagement } \\
\text { for data quality and } \\
\text { completeness }\end{array}$ & $\begin{array}{l}\text { Feedback mechanisms on } \\
\text { the central/federal data portal }\end{array}$ & $\begin{array}{l}\text { Q.70. On the central/federal "one-stop-shop" portal, is there } \\
\text { a user feedback section? }\end{array}$ & Yes/No & 2.e \\
\hline 12 & Data accessibility & $\begin{array}{l}\text { Stakeholder engagement } \\
\text { for data quality }\end{array}$ & $\begin{array}{l}\text { Feedback mechanisms on } \\
\text { the central/federal data portal }\end{array}$ & $\begin{array}{l}\text { Q.70.a. Do you collect information on the number of user } \\
\text { requests sent through the user feedback section of the } \\
\text { central/federal "one-stop-shop" portal? }\end{array}$ & Yes/No & 2.e \\
\hline 13 & Data accessibility & $\begin{array}{l}\text { Stakeholder engagement } \\
\text { for data quality }\end{array}$ & $\begin{array}{l}\text { Feedback mechanisms on } \\
\text { the central/federal data portal }\end{array}$ & Q.70.b. Do you publish this information online? & Yes/No & 2.e \\
\hline 14 & Data accessibility & $\begin{array}{l}\text { Stakeholder engagement } \\
\text { for data quality }\end{array}$ & $\begin{array}{l}\text { Feedback mechanisms on } \\
\text { the central/federal data portal }\end{array}$ & $\begin{array}{l}\text { Q.70.c. Are comments provided in the user feedback } \\
\text { section visible for all visitors? }\end{array}$ & Yes/No & 2.e \\
\hline 15 & Data accessibility & $\begin{array}{l}\text { Stakeholder engagement } \\
\text { for data quality }\end{array}$ & $\begin{array}{l}\text { Feedback mechanisms on } \\
\text { the central/federal data portal }\end{array}$ & $\begin{array}{l}\text { Q.76. Which of the following functions are available on the } \\
\text { central/federal one stop shop portal?: Forums for } \\
\text { discussions }\end{array}$ & Yes/No & 2.e \\
\hline 16 & Data accessibility & $\begin{array}{l}\text { Stakeholder engagement } \\
\text { for data quality }\end{array}$ & $\begin{array}{l}\text { User driven central/federal } \\
\text { data portal }\end{array}$ & $\begin{array}{l}\text { Q.71. On the central/federal one stop shop portal can users } \\
\text { complete the following procedures: Add a dataset }\end{array}$ & Yes/No & 3.e, $6 . a$ \\
\hline 17 & Data accessibility & $\begin{array}{l}\text { Stakeholder engagement } \\
\text { for data quality }\end{array}$ & $\begin{array}{l}\text { User driven central/federal } \\
\text { data portal }\end{array}$ & $\begin{array}{l}\text { Q.71. On the central/federal one stop shop portal can users } \\
\text { complete the following procedures: Add a data vizualisation }\end{array}$ & Yes/No & 3.e, $6 . a$ \\
\hline 18 & Data accessibility & $\begin{array}{l}\text { Stakeholder engagement } \\
\text { for data quality }\end{array}$ & $\begin{array}{l}\text { User driven central/federal } \\
\text { data portal }\end{array}$ & $\begin{array}{l}\text { Q.71.a. If yes, can users be notified about any : Issues } \\
\text { about their data }\end{array}$ & Yes/No & 3.e, 6.a \\
\hline 19 & Data accessibility & $\begin{array}{l}\text { Stakeholder engagement } \\
\text { for data quality }\end{array}$ & $\begin{array}{l}\text { User driven central/federal } \\
\text { data portal }\end{array}$ & $\begin{array}{l}\text { Q.71.a. If yes, can users be notified about any Discussions } \\
\text { about their data? }\end{array}$ & Yes/No & 3.e, $6 . a$ \\
\hline 20 & Data accessibility & $\begin{array}{l}\text { Stakeholder engagement } \\
\text { for data quality }\end{array}$ & $\begin{array}{l}\text { User driven central/federal } \\
\text { data portal }\end{array}$ & $\begin{array}{l}\text { Q.76. Which of the following functions are available on the } \\
\text { central/federal one stop shop portal? - Possibility to receive } \\
\text { notifications when specific datasets are added }\end{array}$ & Yes/No & 2.e \\
\hline 21 & Data accessibility & Implementation & $\begin{array}{l}\text { Adoption of a single entry } \\
\text { point to access Open } \\
\text { Government Data }\end{array}$ & $\begin{array}{l}\text { Q.66. Is there a central/federal one stop shop portal for } \\
\text { open government data? }\end{array}$ & Yes/No & 3.a \\
\hline 22 & data accessibility & Implementation & $\begin{array}{l}\text { Adoption of a single entry } \\
\text { point to access Open } \\
\text { Government Data }\end{array}$ & $\begin{array}{l}\text { Q.66.b. If yes, do visitors need to go through a registration } \\
\text { process to carry out the following actions on the one stop } \\
\text { shop portal: Access/download data }\end{array}$ & Yes/No & 3.d \\
\hline 23 & Data accessibility & Implementation & $\begin{array}{l}\text { Data accessible free of } \\
\text { charge and in open formats } \\
\text { on the central/federal }\end{array}$ & $\begin{array}{l}\text { Q.72. On the central/federal "one-stop-shop" portal, can } \\
\text { users carry out the following actions with the data free of } \\
\text { charge: Download. }\end{array}$ & Yes/No & 3.c \\
\hline
\end{tabular}




\begin{tabular}{|c|c|c|c|c|c|c|}
\hline 24 & Data accessibility & Implementation & $\begin{array}{l}\text { Data accessible free of } \\
\text { charge and in open formats } \\
\text { on the central/federal }\end{array}$ & $\begin{array}{l}\text { Q.75. On the central/federal one stop shop portal, what } \\
\text { proportion of the data are provided: As structured data. }\end{array}$ & $\begin{array}{l}\text { None (0), Some (0.25), Most } \\
(0.75) \text {, Often (1) }\end{array}$ & 4.a \\
\hline 25 & Data accessibility & Implementation & $\begin{array}{l}\text { Data accessible free of } \\
\text { charge and in open formats } \\
\text { on the central/federal }\end{array}$ & $\begin{array}{l}\text { Q.75. On the central/federal one stop shop portal, what } \\
\text { proportion of the data are provided: In multiple formats (i.e. } \\
\text { more than } 1 \text { format). }\end{array}$ & $\begin{array}{l}\text { None (0), Some (0.25), Most } \\
(0.75) \text {, Often (1) }\end{array}$ & 3.b \\
\hline 26 & Data accessibility & Implementation & $\begin{array}{l}\text { Data accessible free of } \\
\text { charge and in open formats } \\
\text { on the central/federal }\end{array}$ & $\begin{array}{l}\text { Q.75. On the central/federal one stop shop portal, what } \\
\text { proportion of the data are provided: In machine readable } \\
\text { formats. }\end{array}$ & $\begin{array}{l}\text { None (0), Some (0.25), Most } \\
(0.75) \text {, Often (1) }\end{array}$ & 3.b \\
\hline 27 & Data accessibility & Implementation & $\begin{array}{l}\text { Systematic provision of } \\
\text { supporting information with } \\
\text { datasets (licensing } \\
\text { conditions, metadata) }\end{array}$ & $\begin{array}{l}\text { Q.73. Are licensing conditions systematically provided with } \\
\text { every datasets on the central/federal one stop shop portal? }\end{array}$ & Yes/No & 3.e, $6 . \mathrm{a}$ \\
\hline 28 & Data accessibility & Implementation & $\begin{array}{l}\text { Systematic provision of } \\
\text { supporting information with } \\
\text { datasets (licensing } \\
\text { conditions, metadata) }\end{array}$ & $\begin{array}{l}\text { Q.74. Is a contact person/organization systematically } \\
\text { provided with the datasets on the central/federal one stop } \\
\text { shop portal? }\end{array}$ & Yes/No & 3.e, $6 . \mathrm{a}$ \\
\hline 29 & Data accessibility & Implementation & $\begin{array}{l}\text { Systematic provision of } \\
\text { supporting information with } \\
\text { datasets (licensing } \\
\text { conditions, metadata) }\end{array}$ & $\begin{array}{c}\text { Q.75.b. On the central/federal "one-stop-shop" portal, what } \\
\text { do the metadata usually cover? Purpose, Characteristics, } \\
\text { Methodology, Period covered, Terminology, Expected date } \\
\text { of registering updated data, Data limitations }\end{array}$ & Each: 0.14286 & 4.c \\
\hline
\end{tabular}

Pillar 3 - Government support to the re-use

\begin{tabular}{|c|c|c|c|c|c|c|}
\hline $\mathbf{N}^{\circ}$ & Pillar & Sub-pillar & Parameter & Variable & Response options & $\begin{array}{c}\text { IODC } \\
\text { principle } \\
\end{array}$ \\
\hline 1 & $\begin{array}{l}\text { Government support } \\
\text { to the re-use }\end{array}$ & $\begin{array}{l}\text { Data promotion initiatives } \\
\text { and partnerships }\end{array}$ & $\begin{array}{l}\text { Existence of data awareness } \\
\text { programmes for businesses and } \\
\text { civil society }\end{array}$ & $\begin{array}{c}\text { Q.42. At the central/federal government are line } \\
\text { ministries/agencies formally encouraged to raise awareness } \\
\text { among businesses regarding open government data } \\
\text { opportunities? }\end{array}$ & Yes/No & 1.c \\
\hline 2 & $\begin{array}{l}\text { Government support } \\
\text { to the re-use }\end{array}$ & $\begin{array}{l}\text { Data promotion initiatives } \\
\text { and partnerships }\end{array}$ & $\begin{array}{l}\text { Existence of data awareness } \\
\text { programmes for businesses and } \\
\text { civil society }\end{array}$ & $\begin{array}{l}\text { Q.46. Since January 2015, have any comprehensive } \\
\text { assessments (e.g. through the form of a report) been } \\
\text { undertaken to better understand the main barriers to the re- } \\
\text { use of open government data among businesses? }\end{array}$ & Yes/No & 6.9 \\
\hline
\end{tabular}




\begin{tabular}{|c|c|c|c|c|c|c|}
\hline 3 & $\begin{array}{l}\text { Government support } \\
\text { to the re-use }\end{array}$ & $\begin{array}{l}\text { Data promotion initiatives } \\
\text { and partnerships }\end{array}$ & $\begin{array}{l}\text { Existence of data awareness } \\
\text { programmes for businesses and } \\
\text { civil society }\end{array}$ & $\begin{array}{c}\text { Q.49. At the central/federal government are line } \\
\text { ministries/agencies formally encouraged to raise awareness } \\
\text { among civil society organizations regarding open government } \\
\text { data opportunities? }\end{array}$ & Yes/No & 1.c \\
\hline 4 & $\begin{array}{l}\text { Government support } \\
\text { to the re-use }\end{array}$ & $\begin{array}{l}\text { Data promotion initiatives } \\
\text { and partnerships }\end{array}$ & $\begin{array}{l}\text { Existence of data awareness } \\
\text { programmes for businesses and } \\
\text { civil society }\end{array}$ & $\begin{array}{l}\text { Q.49a. Do these requirements cover the following civil society } \\
\text { organizations/groups? - Citizens; journalists; academics; } \\
\text { ngos. }\end{array}$ & 0.25 each $($ total $=1)$ & 1.c \\
\hline 5 & $\begin{array}{l}\text { Government support } \\
\text { to the re-use }\end{array}$ & $\begin{array}{l}\text { Data promotion initiatives } \\
\text { and partnerships }\end{array}$ & $\begin{array}{l}\text { Existence of data awareness } \\
\text { programmes for businesses and } \\
\text { civil society }\end{array}$ & $\begin{array}{l}\text { Q.52. Since January 2015, have any comprehensive } \\
\text { assessments (e.g. through the form of a report) been } \\
\text { undertaken to better understand the main barriers to the reuse } \\
\text { of open government data among civil society organisations? }\end{array}$ & Yes/No & $6 . g$ \\
\hline 6 & $\begin{array}{l}\text { Government support } \\
\text { to the re-use }\end{array}$ & $\begin{array}{l}\text { Data promotion initiatives } \\
\text { and partnerships }\end{array}$ & $\begin{array}{l}\text { Existence of data awareness } \\
\text { programmes for businesses and } \\
\text { civil society }\end{array}$ & $\begin{array}{l}\text { Q.55. Since January } 2015 \text {, has the central/federal government } \\
\text { supported projects from civil society organizations that aimed } \\
\text { to identify solutions to public policy challenges through the use } \\
\text { of open government data? }\end{array}$ & Yes/No & $5 . g$ \\
\hline 7 & $\begin{array}{l}\text { Government support } \\
\text { to the re-use }\end{array}$ & $\begin{array}{l}\text { Data promotion initiatives } \\
\text { and partnerships }\end{array}$ & $\begin{array}{l}\text { Existence of data awareness } \\
\text { programmes for businesses and } \\
\text { civil society }\end{array}$ & $\begin{array}{l}\text { Q.55.a. Did some of these projects focus on identifying policy } \\
\text { solutions to challenges faced by marginalized communities } \\
\text { (e.g. specific ethnic groups, social groups)? }\end{array}$ & Yes/No & $5 . g$ \\
\hline 8 & $\begin{array}{l}\text { Government support } \\
\text { to the re-use }\end{array}$ & $\begin{array}{l}\text { Data promotion initiatives } \\
\text { and partnerships }\end{array}$ & $\begin{array}{l}\text { Frequency of specific events to } \\
\text { support data re-use among } \\
\text { businesses and the civil society }\end{array}$ & $\begin{array}{l}\text { Q.44. In practice, since January } 2015 \text { how often have } \\
\text { representatives from central/federal ministries/agencies been } \\
\text { involved in the following events/activities aimed at promoting } \\
\text { the reuse of open government data among businesses? - } \\
\text { Conduct focus groups/information sessions with business } \\
\text { representatives to understand their data needs. }\end{array}$ & $\begin{array}{l}\text { Never }(0) \text {, rarely }(0.25) \text {, } \\
\text { sometimes }(0.75) \text {, often } \\
\text { (1) }\end{array}$ & 1.c \\
\hline 9 & $\begin{array}{l}\text { Government support } \\
\text { to the re-use }\end{array}$ & $\begin{array}{l}\text { Data promotion initiatives } \\
\text { and partnerships }\end{array}$ & $\begin{array}{l}\text { Frequency of specific events to } \\
\text { support data re-use among } \\
\text { businesses and the civil society }\end{array}$ & $\begin{array}{l}\text { Q.44. In practice, since January } 2015 \text { how often have } \\
\text { representatives from central/federal ministries/agencies been } \\
\text { involved in the following events/activities aimed at promoting } \\
\text { the reuse of open government data among businesses? - } \\
\text { Organize hackathons events. }\end{array}$ & $\begin{array}{l}\text { Never }(0) \text {, rarely }(0.25) \text {, } \\
\text { sometimes }(0.75) \text {, often } \\
\text { (1) }\end{array}$ & 6.c \\
\hline 10 & $\begin{array}{l}\text { Government support } \\
\text { to the re-use }\end{array}$ & $\begin{array}{l}\text { Data promotion initiatives } \\
\text { and partnerships }\end{array}$ & $\begin{array}{l}\text { Frequency of specific events to } \\
\text { support data re-use among } \\
\text { businesses and the civil society }\end{array}$ & $\begin{array}{l}\text { Q.44. In practice, since January } 2015 \text { how often have } \\
\text { representatives from central/federal ministries/agencies been } \\
\text { involved in the following events/activities aimed at promoting } \\
\text { the reuse of open government data among businesses? - } \\
\text { Organize co-creation events (e.g. app development contest, } \\
\text { data vizualisation challenge). }\end{array}$ & $\begin{array}{l}\text { Never }(0) \text {, rarely }(0.25) \text {, } \\
\text { sometimes }(0.75) \text {, often } \\
(1)\end{array}$ & 6.c \\
\hline
\end{tabular}




\begin{tabular}{|c|c|c|c|c|c|c|}
\hline 11 & $\begin{array}{l}\text { Government support } \\
\text { to the re-use }\end{array}$ & $\begin{array}{l}\text { Data promotion initiatives } \\
\text { and partnerships }\end{array}$ & $\begin{array}{l}\text { Frequency of specific events to } \\
\text { support data re-use among } \\
\text { businesses and the civil society }\end{array}$ & $\begin{array}{l}\text { Q.50. In practice, since January } 2015 \text { how often have } \\
\text { central/federal ministries/agencies participated in the following } \\
\text { events aimed at promoting the reuse of open government data } \\
\text { among the civil society? - Organise a conference on the } \\
\text { opportunities/benefits provided by open government datasets } \\
\text { to the civil society. }\end{array}$ & $\begin{array}{l}\text { Never }(0) \text {, rarely }(0.25) \text {, } \\
\text { sometimes }(0.75) \text {, often } \\
\text { (1) }\end{array}$ & 1.c \\
\hline 12 & $\begin{array}{l}\text { Government support } \\
\text { to the re-use }\end{array}$ & $\begin{array}{l}\text { Data promotion initiatives } \\
\text { and partnerships }\end{array}$ & $\begin{array}{l}\text { Frequency of specific events to } \\
\text { support data re-use among } \\
\text { businesses and the civil society }\end{array}$ & $\begin{array}{l}\text { Q.50. In practice, since January } 2015 \text { how often have } \\
\text { central/federal ministries/agencies participated in the following } \\
\text { events aimed at promoting the reuse of open government data } \\
\text { among the civil society? - Attend conferences organized by a } \\
\text { third party to present the opportunities/benefits of open } \\
\text { government datasets to civil society organizations. }\end{array}$ & $\begin{array}{l}\text { Never }(0) \text {, rarely }(0.25) \text {, } \\
\text { sometimes }(0.75), \text { often } \\
(1)\end{array}$ & 1.c \\
\hline 13 & $\begin{array}{l}\text { Government support } \\
\text { to the re-use }\end{array}$ & $\begin{array}{l}\text { Data promotion initiatives } \\
\text { and partnerships }\end{array}$ & $\begin{array}{l}\text { Frequency of specific events to } \\
\text { support data re-use among } \\
\text { businesses and the civil society }\end{array}$ & $\begin{array}{l}\text { Q.50. In practice, since January } 2015 \text { how often have } \\
\text { central/federal ministries/agencies participated in the following } \\
\text { events aimed at promoting the reuse of open government data } \\
\text { among the civil society? - Conduct focus groups/information } \\
\text { sessions with civil society representatives to understand their } \\
\text { data needs. }\end{array}$ & $\begin{array}{l}\text { Never }(0) \text {, rarely }(0.25) \text {, } \\
\text { sometimes }(0.75) \text {, often } \\
(1)\end{array}$ & 5.e. \\
\hline 14 & $\begin{array}{l}\text { Government support } \\
\text { to the re-use }\end{array}$ & $\begin{array}{l}\text { Data promotion initiatives } \\
\text { and partnerships }\end{array}$ & $\begin{array}{l}\text { Existence of formal partnerships } \\
\text { with businesses and the civil } \\
\text { society to support data re-use }\end{array}$ & $\begin{array}{l}\text { Q.47. Since January } 2015 \text {, has the central/federal government } \\
\text { developed partnership(s) with business incubators to support } \\
\text { the reuse of open data by companies and start-ups? }\end{array}$ & Yes/No & 6.b. \\
\hline 15 & $\begin{array}{l}\text { Government support } \\
\text { to the re-use }\end{array}$ & $\begin{array}{l}\text { Data promotion initiatives } \\
\text { and partnerships }\end{array}$ & $\begin{array}{l}\text { Existence of formal partnerships } \\
\text { with businesses and the civil } \\
\text { society to support data re-use }\end{array}$ & $\begin{array}{l}\text { Q.53. Since January } 2015 \text {, has the central/federal government } \\
\text { developed partnership(s) with civil society organizations to } \\
\text { support greater reuse of open government data? }\end{array}$ & Yes/No & 6.b. \\
\hline 16 & $\begin{array}{l}\text { Government support } \\
\text { to the re-use }\end{array}$ & Data literacy programmes & $\begin{array}{l}\text { Frequency of training events for } \\
\text { public officials to support data- } \\
\text { reuse }\end{array}$ & $\begin{array}{l}\text { Q.58. Is there a central/federal programme which aims at } \\
\text { supporting open data literacy among public servants? }\end{array}$ & Yes/No & 5.c. \\
\hline 17 & $\begin{array}{l}\text { Government support } \\
\text { to the re-use }\end{array}$ & Data literacy programmes & $\begin{array}{l}\text { Frequency of training events for } \\
\text { public officials to support data- } \\
\text { reuse }\end{array}$ & $\begin{array}{l}\text { Q.59. On average, how often do central/federal } \\
\text { ministries/agencies organize training sessions on the reuse of } \\
\text { open government data targeted at public servants? }\end{array}$ & $\begin{array}{l}\text { Never }(0) \text {, rarely }(0.25) \text {, } \\
\text { sometimes }(0.75) \text {, often } \\
(1)\end{array}$ & 5.c. \\
\hline 18 & $\begin{array}{l}\text { Government support } \\
\text { to the re-use }\end{array}$ & Data literacy programmes & $\begin{array}{l}\text { Frequency of training events for } \\
\text { public officials to support data- } \\
\text { reuse }\end{array}$ & $\begin{array}{l}\text { Q.59.a. Do you collect information on the effectiveness of } \\
\text { these training sessions (e.g. satisfaction survey, statistics, } \\
\text { indicators)? }\end{array}$ & Yes/No & 5.c. \\
\hline 19 & $\begin{array}{l}\text { Government support } \\
\text { to the re-use }\end{array}$ & Data literacy programmes & $\begin{array}{l}\text { Frequency of training events for } \\
\text { public officials to support data- } \\
\text { reuse }\end{array}$ & $\begin{array}{l}\text { Q.60. At the central/federal level of government, are there } \\
\text { guidelines available for public servants on how best to } \\
\text { leverage open government data in policy development } \\
\text { processes? }\end{array}$ & Yes/No & 5.c. \\
\hline
\end{tabular}


Frequency of training events for public officials to support datareuse

Frequency of information to the re-use Data literacy programmes public officials to support datare-use

Frequency of information sessions and focus groups for public officials to support datare-use

Frequency of information sessions and focus groups for public officials to support datare-use to the re-use

Frequency of information sessions and focus groups for public officials to support datare-use to the re-use

Q.64. Since January 2012, have you conducted a large scale consultation with Ministries/agencies to collect feedback from them on how best to support data reuse at the central/federa level of government?

Q.56. At the central/federal government are line

ministries/agencies formally encouraged to raise awareness among public servants regarding the opportunities to reuse open government data inside the public sector?

Data literacy programmes

24 Government support Data literacy programmes

Q.57. In practice, since January 2015 how often have central/federal ministries/agencies participated in the following Never (0), rarely $(0.25)$ cents aimed at promoting the reuse of open government data (1) often sessions with public servants to understand their data needs.

\section{Q.57. In practice, since January 2015 how often have} central/federal ministries/agencies participated in the following among sometimes (0.75), often to public servants on new developments regarding open government data policies.

Q.57.a. Do these events also involve public servants with managerial/leadership positions?

Yes/No

\section{Conducted or financed research} on socio economic impact of open data

Q.48. Since January 2015 , has the central/federal government: Conducted or financed research on the economic impact of open government data?

Yes/No

Conducted or financed research on socio economic impact of open data

Q.54. Since January 2015, has the central/federal

government: Conducted or financed research on the social impact of open government data?

6.e.

Conducted or financed research on socio economic impact of open data

Q.65. Do you measure the impact of open government data on public sector performance?

Yes/No 6.e.

Monitor and promote online initiatives re-using open government data

28 Government support

Monitoring impact

29 Government support $\quad$ Monitoring impact $\quad \begin{gathered}\text { Monitor and promote online } \\ \text { initiatives re-using open }\end{gathered}$ to the re-use
Q.78. On the central/federal government data portal do you promote initiatives that re-use government data?

Q.79. For which of the following groups do you promote
initiatives that re-use government data? - Businesses.
Q.79. For which of the following groups do you promote government data 


\begin{tabular}{|c|c|c|c|c|c|c|}
\hline 30 & $\begin{array}{l}\text { Government support } \\
\text { to the re-use }\end{array}$ & Monitoring impact & $\begin{array}{l}\text { Monitor and promote online } \\
\text { initiatives re-using open } \\
\text { government data }\end{array}$ & $\begin{array}{l}\text { Q.79. For which of the following groups do you promote } \\
\text { initiatives that re-use government data? - Civil society. }\end{array}$ & Yes/No & 5.a. \\
\hline 31 & $\begin{array}{l}\text { Government support } \\
\text { to the re-use }\end{array}$ & Monitoring impact & $\begin{array}{l}\text { Monitor and promote online } \\
\text { initiatives re-using open } \\
\text { government data }\end{array}$ & $\begin{array}{l}\text { Q.79. For which of the following groups do you promote } \\
\text { initiatives that re-use government data? - Public servants. }\end{array}$ & Yes/No & 5.a. \\
\hline 32 & $\begin{array}{l}\text { Government support } \\
\text { to the re-use }\end{array}$ & Monitoring impact & $\begin{array}{l}\text { Monitor and promote online } \\
\text { initiatives re-using open } \\
\text { government data }\end{array}$ & $\begin{array}{l}\text { Q.80. Which type of reuse of public data are presented on the } \\
\text { OGD one stop shop portal? - Data visualisation. }\end{array}$ & Yes/No & 5.a. \\
\hline 33 & $\begin{array}{l}\text { Government support } \\
\text { to the re-use }\end{array}$ & Monitoring impact & $\begin{array}{l}\text { Monitor and promote online } \\
\text { initiatives re-using open } \\
\text { government data }\end{array}$ & $\begin{array}{l}\text { Q.80. Which type of reuse of public data are presented on the } \\
\text { OGD one stop shop portal? - Applications. }\end{array}$ & Yes/No & 5.a. \\
\hline 34 & $\begin{array}{l}\text { Government support } \\
\text { to the re-use }\end{array}$ & Monitoring impact & $\begin{array}{l}\text { Monitor and promote online } \\
\text { initiatives re-using open } \\
\text { government data }\end{array}$ & $\begin{array}{l}\text { Q.80. Which type of reuse of public data are presented on the } \\
\text { OGD one stop shop portal? - Press articles. }\end{array}$ & Yes/No & 5.a. \\
\hline 35 & $\begin{array}{l}\text { Government support } \\
\text { to the re-use }\end{array}$ & Monitoring impact & $\begin{array}{l}\text { Monitor and promote online } \\
\text { initiatives re-using open } \\
\text { government data }\end{array}$ & $\begin{array}{l}\text { Q.80. Which type of reuse of public data are presented on the } \\
\text { OGD one stop shop portal? - APIs. }\end{array}$ & Yes/No & 5.a. \\
\hline 36 & $\begin{array}{l}\text { Government support } \\
\text { to the re-use }\end{array}$ & Monitoring impact & $\begin{array}{l}\text { Monitor and promote online } \\
\text { initiatives re-using open } \\
\text { government data }\end{array}$ & $\begin{array}{l}\text { Q.80. Which type of reuse of public data are presented on the } \\
\text { OGD one stop shop portal? - Blog articles. }\end{array}$ & Yes/No & 5.a. \\
\hline 37 & $\begin{array}{l}\text { Government support } \\
\text { to the re-use }\end{array}$ & Monitoring impact & $\begin{array}{l}\text { Monitor and promote online } \\
\text { initiatives re-using open } \\
\text { government data }\end{array}$ & $\begin{array}{l}\text { Q.80. Which type of reuse of public data are presented on the } \\
\text { OGD one stop shop portal? - Academic papers. }\end{array}$ & Yes/No & 5.a. \\
\hline
\end{tabular}


Annex D: List of sub-principles from the International Open Data Charter not covered in the 2017 OECD OURdata index

\begin{tabular}{|c|c|c|c|}
\hline Topic & $\mathrm{N}^{\circ}$ & Principle & Reason \\
\hline $\begin{array}{l}\text { International } \\
\text { knowledge sharing }\end{array}$ & $\begin{array}{l}4 . d \& \\
6 . f\end{array}$ & $\begin{array}{l}\text { 4d. "Engage with domestic and international standards bodies and } \\
\text { other standard setting initiatives to encourage increased interoperability } \\
\text { between existing international standards, support the creation of } \\
\text { common, global data standards where they do not already exist, and } \\
\text { ensure that any new data standards we create are, to the greatest extent } \\
\text { possible, interoperable with existing standards"; } \\
\text { 6.f. "Build capacity and share technical expertise and experience with } \\
\text { other governments and international organizations around the world, } \\
\text { ensuring that everyone can reap the benefits of open data" }\end{array}$ & $\begin{array}{l}\text { - Outside of the scope of this exercise } \\
\text { Engagement of countries with international } \\
\text { organizations is very hard to capture in an } \\
\text { index }\end{array}$ \\
\hline $\begin{array}{l}\text { Engagement with } \\
\text { subnational levels } \\
\text { of government and } \\
\text { educational } \\
\text { institutions }\end{array}$ & $\begin{array}{l}\text { 4.e \& } \\
6 . d\end{array}$ & $\begin{array}{l}\text { 4.e. Map local standards and identifiers to emerging globally agreed } \\
\text { standards and share the results publicly } \\
\text { 6.d. Engage with schools and post-secondary education institutions to } \\
\text { support increased open data research and to incorporate data literacy } \\
\text { into educational curricula }\end{array}$ & $\begin{array}{l}\text { - Outside the scope of this exercise } \\
\text { - OURdata Index covers practices in place at } \\
\text { the central/federal level } \\
\text { - Local governments and the education sector } \\
\text { are not under the responsibility of } \\
\text { central/federal governments in a number of } \\
\text { OECD member countries }\end{array}$ \\
\hline $\begin{array}{l}\text { Lifecycle dataset } \\
\text { management }\end{array}$ & 2.f & $\begin{array}{l}\text { Apply consistent information lifecycle management practices, and } \\
\text { ensure historical copies of datasets are preserved, archived, and kept } \\
\text { accessible as long as they retain value }\end{array}$ & $\begin{array}{l}\text { Difficult to capture } \\
\text { - The concept of retaining value is ultimately } \\
\text { subjective } \\
\text { - Indirectly captured when measuring } \\
\text { stakeholder engagement for data release } \\
\text { and for data accessibility. } \\
\text { - More work needed to better understand } \\
\text { governments' lifecycle dataset management }\end{array}$ \\
\hline
\end{tabular}




\section{Annex E: Results from sensitivity testing}

Monte Carlo simulations generate interval of values that reflect the range of possible scores for indicators in the case of each country, depending on one thousand different weighting scenarios. The results are presented in the figures below. Vertical lines represent the $90 \%$ confidence intervals derived from the random weights analysis.

The size of the interval varies depending on countries' open government data profile (mixed or rather even). Countries with an even answer profile, i.e. which gave similar answers for the majority of questions, will fall into a narrow interval, while countries with an uneven profile will fall into a broader interval. (See Freudenberg, 2003).

The results from the sensitivity analyses at various levels (pillar and sub-pillar level) show that, for the vast majority of countries, total scores are not very sensitive to the choice of values given to the categories. The total scores of Austria, Estonia and Chile appear to be more sensitive to the weightings applied. At the subpillar level, pillar 1 is less sensitive to weightings than pillars 2 and 3. It is important to note that not all the combinations of weights used to create these intervals can be viewed as realistic outcomes (Arndt and al, 2015).

One possible practical application for the analysis of the upper and lower bounds of these intervals is to consider how countries can be grouped together with a strong degree of confidence (Andt, 2015). Focusing on total scores, countries such as Canada, France, Finland, Korea, Japan, Mexico, Netherlands, Spain, the United Kingdom and the United-States score above the OECD average for $90 \%$ of random combinations. By contrast Latvia and Turkey score well below the OECD average and other OECD countries no matter the combination of weights used.

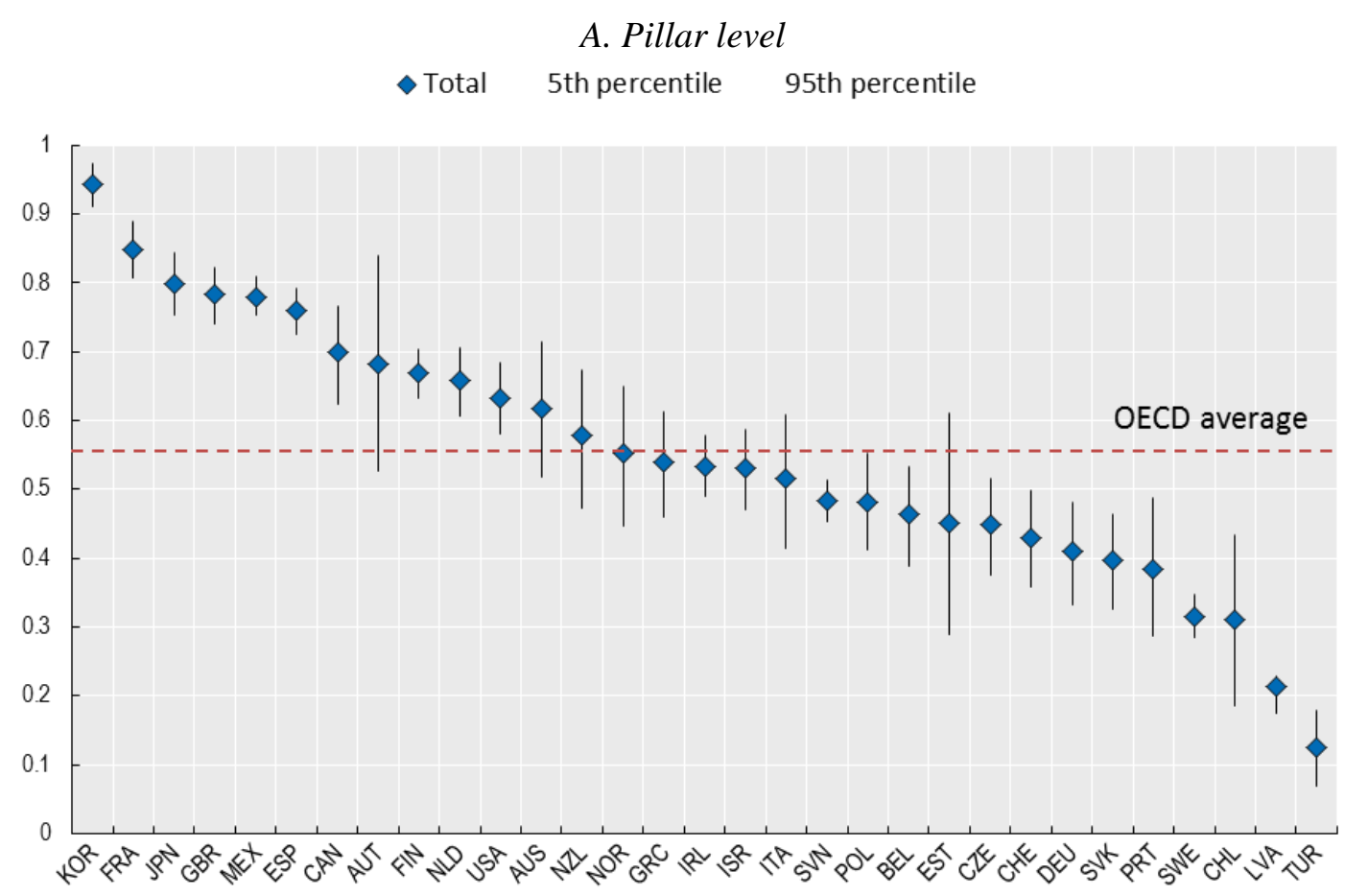


Note: Results from the Monte Carlo simulation where 1,000 different weights were assigned to pillar 1, pillar 2 and pillar 3. Diamonds represent the indicator scores and vertical lines represent the $90 \%$ confidence intervals derived from the random weights analysis.

Source: OECD analysis

\section{Factor level: Pillar 1}

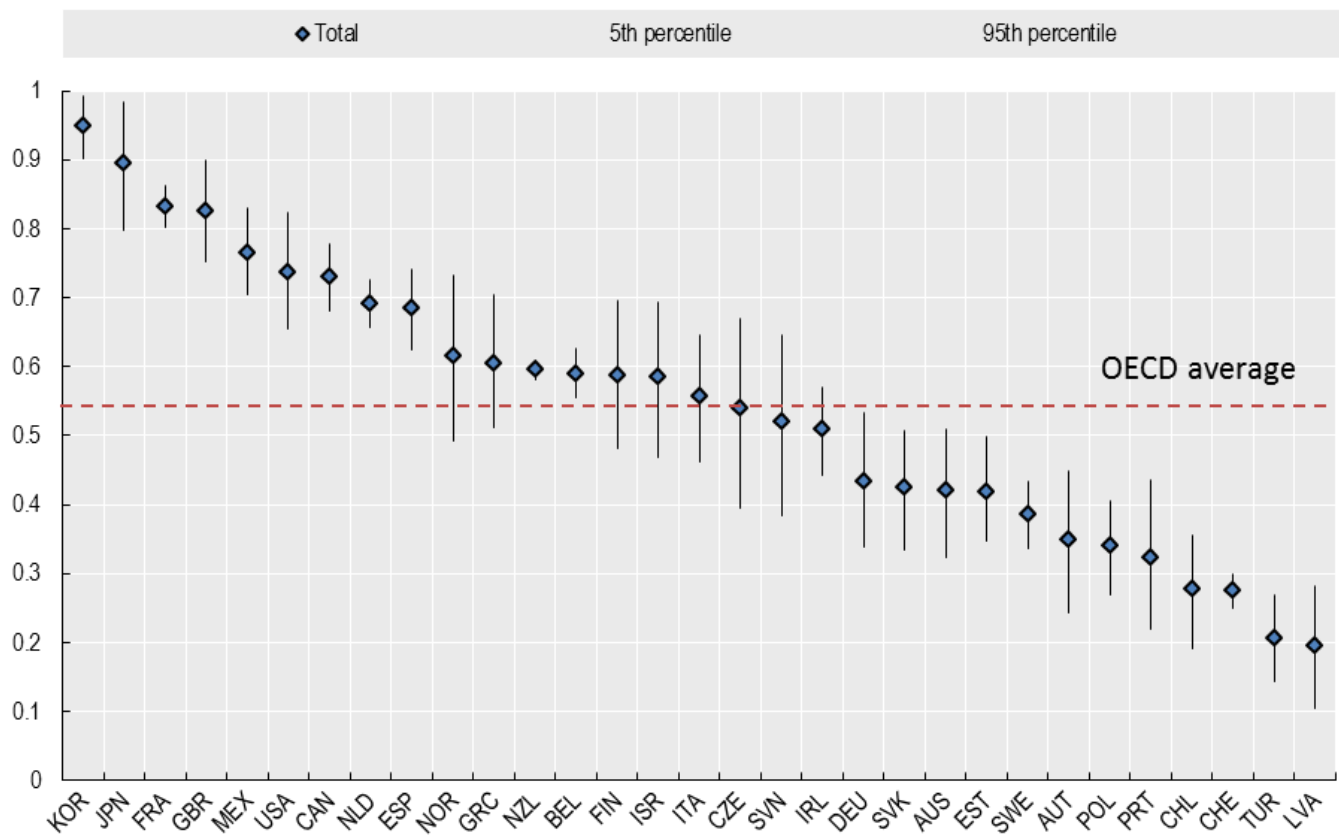

Note: Results from the Monte Carlo simulation where 1,000 different weights were assigned to each sub-pillars. Diamonds represent the indicator scores and vertical lines represent the $90 \%$ confidence intervals derived from the random weights analysis. Source: OECD analysis

Factor level: Pillar 2

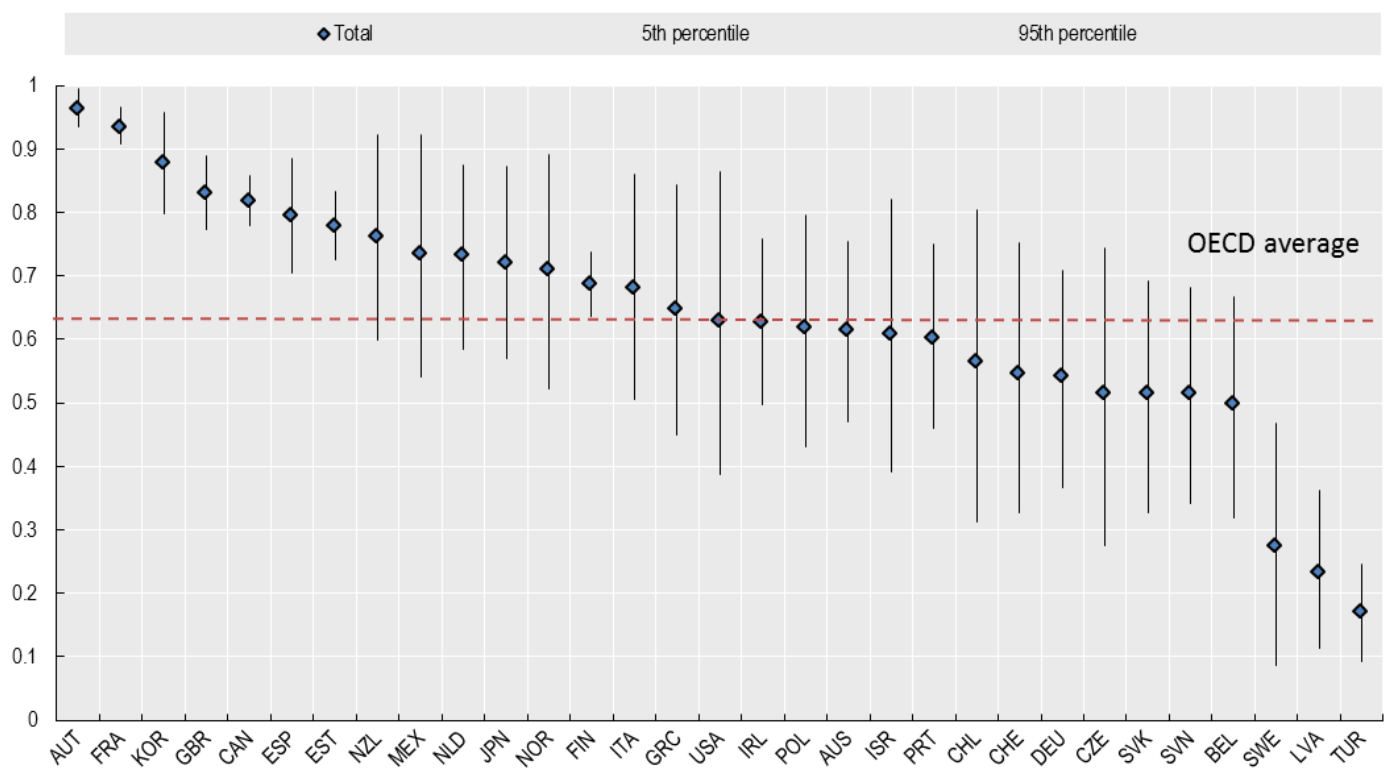

Note: Results from the Monte Carlo simulation where 1,000 different weights were assigned to each sub-pillars. Diamonds represent the indicator scores and vertical lines represent the $90 \%$ confidence intervals derived from the random weights analysis. 
Factor level: Pillar 3

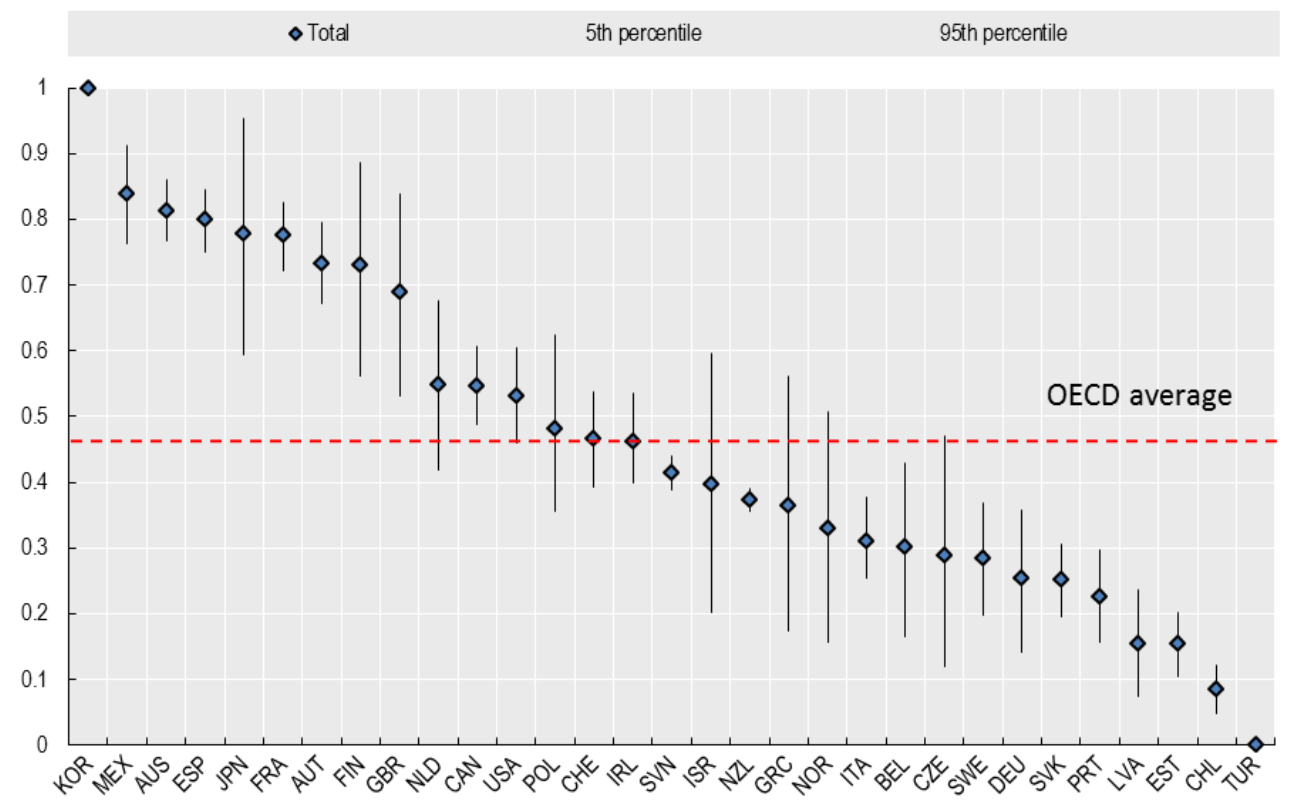

Note: Results from the Monte Carlo simulation where 1,000 different weights were assigned to each sub-pillars. Diamonds represent the indicator scores and vertical lines represent the $90 \%$ confidence intervals derived from the random weights analysis. Source: OECD analysis 


\section{Annex F: Exploring validity (construct and convergent) and reliability}

This section looks at different ways to test the accuracy of the 2017 OURdata Index construct and in particular validity (construct and convergent) and reliability. Considering the limitations in terms of sample size, methodologies and the few number of external sources available this should be interpreted as a first attempt to test the accuracy of the construct rather than final and definitive conclusions.

\section{Construct validity}

Construct validity can be tested by looking at whether different dimensions of open government data as measured through the same assessment are correlated with each other (Gonzales, 2017). This analysis can help to highlight whether the different dimensions of governance are capturing different facets of the same phenomenon, or are referring to fundamentally different phenomena.

Overall there is a strong and statistically significant correlation between the 3 pillars ( $r>0.6)$ of the 2017 OURdata Index which suggests that they potentially measure a related underlying phenomenon. At the same time the levels of correlation remain reasonable and indicate no signs of redundancy.

\begin{tabular}{|l|c|c|c|}
\hline & $\begin{array}{c}\text { Pillar 1: Data } \\
\text { availability }\end{array}$ & $\begin{array}{c}\text { Pillar 2: Data } \\
\text { accessibility }\end{array}$ & $\begin{array}{c}\text { Pillar 3: Government } \\
\text { support for data re-use }\end{array}$ \\
\hline $\begin{array}{l}\text { Pillar 1: Data } \\
\text { availability }\end{array}$ & 1.00 & & \\
\hline $\begin{array}{l}\text { Pillar 2: Data } \\
\text { accessibility }\end{array}$ & $\mathbf{0 . 6 8 * * *}$ & 1.00 & 1.00 \\
\hline $\begin{array}{l}\text { Pillar 3: Government } \\
\text { support for data re-use }\end{array}$ & $\mathbf{0 . 7 2 * * *}$ & $\mathbf{0 . 7 0} * * *$ & \\
\hline
\end{tabular}

Note: Pearson correlation coefficients between the 3 pillars of the OURdata Index. “***”denotes significance at the $1 \%$ level. Source: OECD analysis

Construct validity can also be tested by looking at whether a construct correlates well with another measure for which theory suggests there should be some level of correlation. There is a statistically significant strong positive correlation ( $r=0.69$ ) between the OECD 2017 OURdata Index (total score) and the 2017 Open Data Barometer (impact score). The "impact" dimension of the Open Barometer captures political, economic and social impacts of open government data. The measurement approach "treats online, mainstream media and academic publications about open data impacts as a proxy for existence of impacts, with researchers asked to score the extent of impact on a $0-10$ scale". The fact that the countries scoring well on the OURdata Index also tend to perform well when it comes to impact is an indication of construct validity since the assumption is that the adoption and implementation of adequate open government data policies and practices should in theory lead to greater impact. However, further research would be needed to establish any causal links between open government data policies and practices and socio-economic impact. 
Correlation between the 2017 OURdata Index and the 2017 Open Data Barometer (impact score)

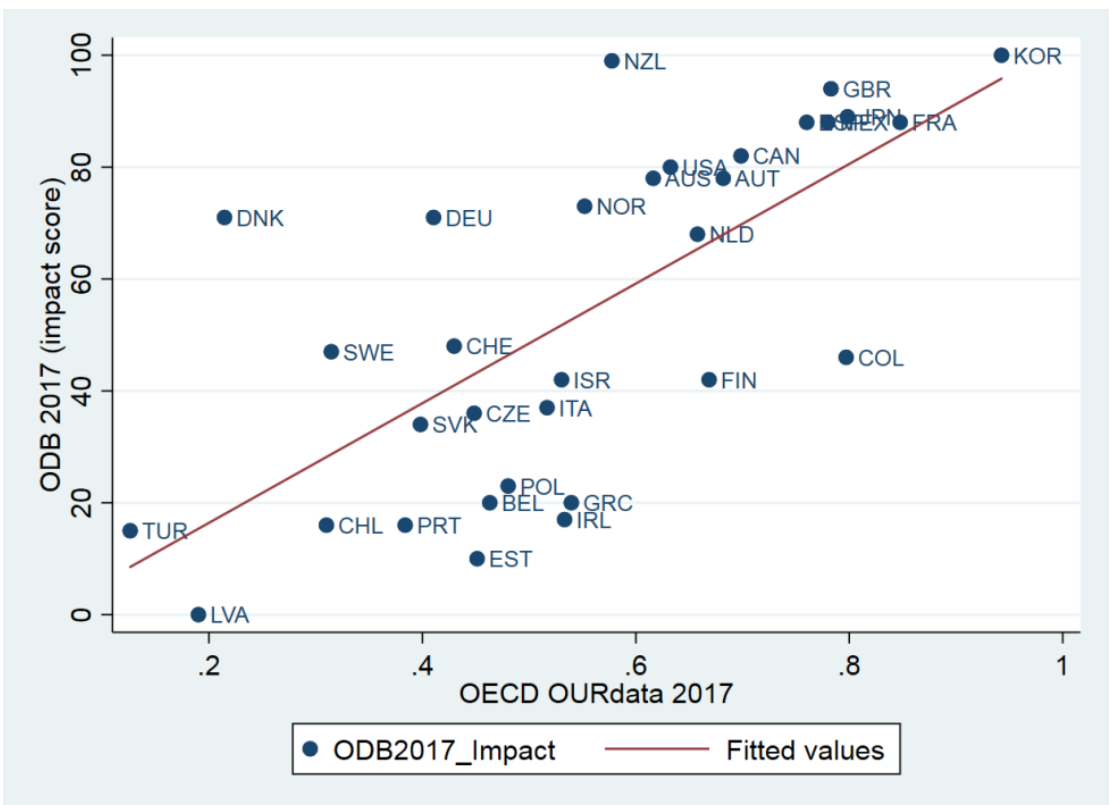

Source: OECD analysis based on Government at a Glance 2017 and the Open data Barometer 2017.

\section{Convergent validity}

A way of testing the convergent validity of an indicator is to compare the indicator vis-à-vis another indicator which aims to capture a related underlying phenomenon.

Despite differences in methodologies and data sources, the Open Data Barometer measures a phenomenon which, in theory, should be close to the phenomenon captured by the 2017 OECD OURdata Index. As expected, there is indeed a statistically significant strong positive correlation $(r=0.63)$ between the OECD 2017 OURdata Index (total score) and the 2017 Open Data Barometer (total score). This suggests that the two indicators measure an underlying concept/phenomenon which is not completely different (as theory would suggest). 


\section{Correlation between the 2017 OURdata Index and the 2017 Open Data Barometer (total score)}

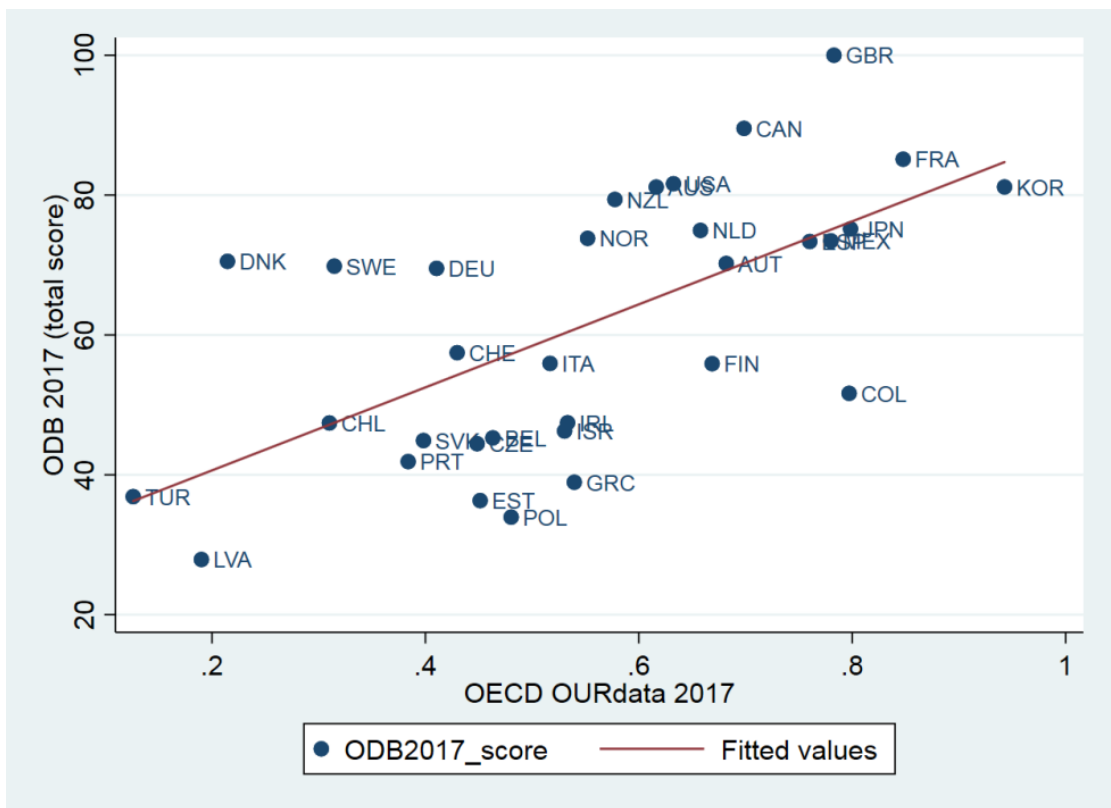

Source: OECD analysis based on Government at a Glance 2017 and the Open data Barometer 2017.

Focusing only on pillar 1 data availability, there is a moderately strong correlation between the OECD 2017 OURdata Index pillar 1 "data availability" and the 2016 Global Open Data Index from the Open Knowledge Foundation which is an independent assessment of open government data publication and datasets from a civic perspective. Although the two indicators have methodological differences in terms of the concept that they aim to measure and the data collection method, the fact that there is a positive and statistically significant correlation between the two measures $(r=0.50)$ indicates that they are not capturing something radically different.

By contrast, the two measures (from the OECD and from the Open Knowledge Foundation) are negatively correlated to the 2015 EU Open Data Monitor. This suggests that this third measure is measuring something different from the OECD and Open Knowledge Foundation indicators.

\begin{tabular}{|l|c|c|c|}
\hline & $\begin{array}{c}\text { OECD OURdata Index } \\
2017\end{array}$ & $\begin{array}{c}\text { Global Open Data Index } \\
\text { Total score }\end{array}$ & $\begin{array}{c}\text { EU Open Data Monitor } \\
\text { Data availability score }\end{array}$ \\
\hline $\begin{array}{l}\text { OECD OURdata Index 2017 } \\
\text { Pillar 1: Data availability }\end{array}$ & 1 & & \\
\hline $\begin{array}{l}\text { Global Open Data Index } \\
\text { Total score }\end{array}$ & $\mathbf{0 . 5 0 * * *}$ & 1 & \\
\hline $\begin{array}{l}\text { EU Open Data Monitor } \\
\text { Data availability score }\end{array}$ & -0.06 & -0.0086 & 1 \\
\hline
\end{tabular}

Note: Pearson correlation coefficients between the 3 pillars of the OURdata Index. "***”"denotes significance at the $1 \%$ level. Source: OECD analysis 


\section{Reliability}

One way of testing the reliability of a construct is whether over different period of times the construct produces consistent results. The pilot version of the 2015 OURdata Index was constructed using a similar data source and framework. Although open government data is an area which is rapidly evolving and that the underlying data and methodology has changed between 2015 and 2017, there should be a certain level of consistency in the results. As expected, there is a statistically significant positive correlation $(r=0.71)$ between the OURdata Index 2015 and 2017.

Correlation between the OECD OURdata Index 2015 and 2017

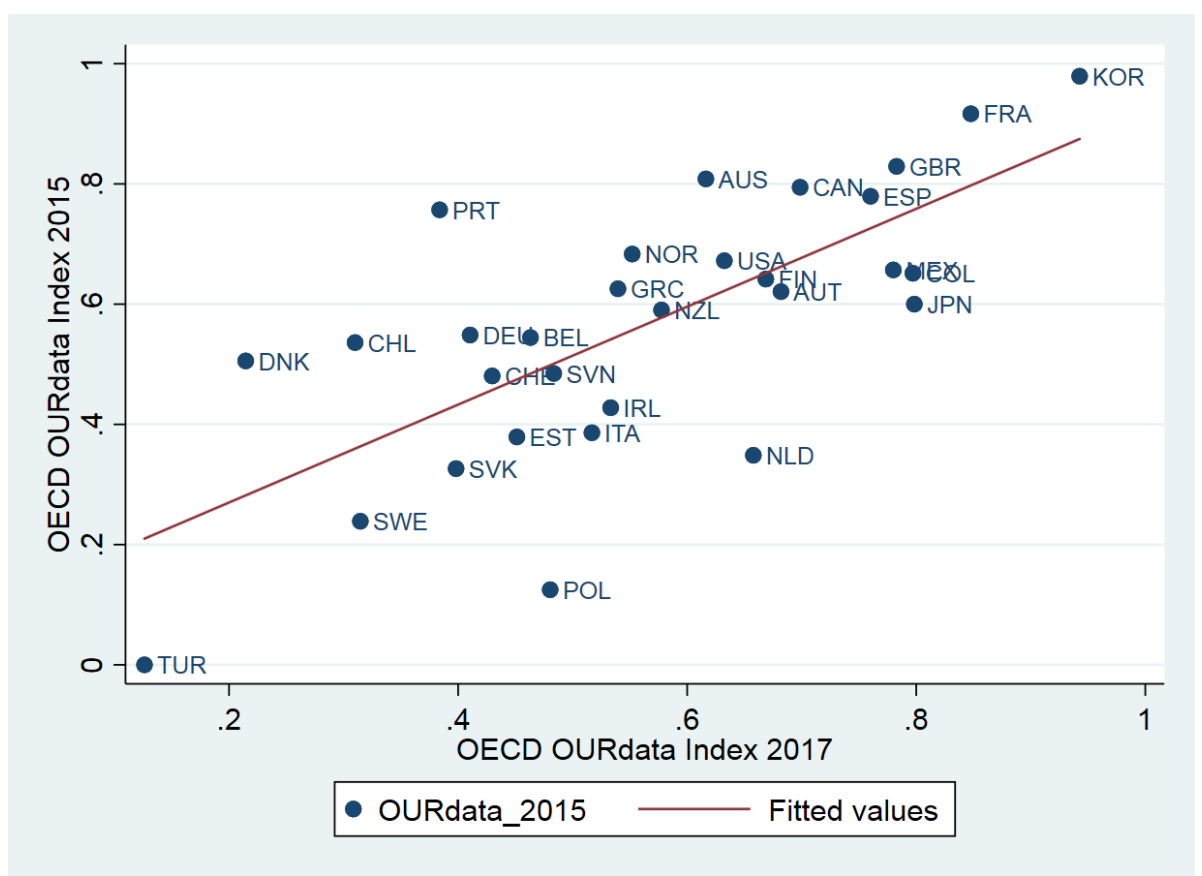

Source: OECD analysis based on Government at a Glance 2015 and 2017 